\title{
Groundwater impacts on surface water quality and nutrient loads in lowland polder catchments: monitoring the greater Amsterdam area
}

\author{
Liang Yu ${ }^{1}$, Joachim Rozemeijer ${ }^{2}$, Boris M. van Breukelen ${ }^{3}$, Maarten Ouboter ${ }^{4}$, Corné van der Vlugt $^{4}$, and \\ Hans Peter Broers ${ }^{5}$ \\ ${ }^{1}$ Faculty of Science, Vrije University Amsterdam, Amsterdam, 1181HV, the Netherlands \\ ${ }^{2}$ Deltares, Utrecht, 3508 TC, the Netherlands \\ ${ }^{3}$ Department of Water Management, Faculty of Civil Engineering and Geosciences, \\ Delft University of Technology, Stevinweg 1, 2628 CN Delft, the Netherlands \\ ${ }^{4}$ Waternet Water Authority, Amsterdam, 1096 AC, the Netherlands \\ ${ }^{5}$ TNO Geological Survey of the Netherlands, Utrecht, $3584 \mathrm{CB}$, the Netherlands
}

Correspondence: Hans Peter Broers (hans-peter.broers@tno.nl)

Received: 20 February 2017 - Discussion started: 17 March 2017

Revised: 27 September 2017 - Accepted: 11 October 2017 - Published: 22 January 2018

\begin{abstract}
The Amsterdam area, a highly manipulated delta area formed by polders and reclaimed lakes, struggles with high nutrient levels in its surface water system. The polders receive spatially and temporally variable amounts of water and nutrients via surface runoff, groundwater seepage, sewer leakage, and via water inlets from upstream polders. Diffuse anthropogenic sources, such as manure and fertiliser use and atmospheric deposition, add to the water quality problems in the polders. The major nutrient sources and pathways have not yet been clarified due to the complex hydrological system in lowland catchments with both urban and agricultural areas. In this study, the spatial variability of the groundwater seepage impact was identified by exploiting the dense groundwater and surface water monitoring networks in Amsterdam and its surrounding polders. A total of 25 variables (concentrations of total nitrogen (TN), total phosphorus (TP), $\mathrm{NH}_{4}, \mathrm{NO}_{3}, \mathrm{HCO}_{3}, \mathrm{SO}_{4}, \mathrm{Ca}$, and $\mathrm{Cl}$ in surface water and groundwater, $\mathrm{N}$ and $\mathrm{P}$ agricultural inputs, seepage rate, elevation, land-use, and soil type) for 144 polders were analysed statistically and interpreted in relation to sources, transport mechanisms, and pathways. The results imply that groundwater is a large source of nutrients in the greater Amsterdam mixed urban-agricultural catchments. The groundwater nutrient concentrations exceeded the surface water environmental quality standards (EQSs) in $93 \%$ of the polders for TP and in $91 \%$ for TN. Groundwater outflow into the polders thus adds to nutrient levels in the surface water. High correla-
\end{abstract}

tions ( $R^{2}$ up to 0.88 ) between solutes in groundwater and surface water, together with the close similarities in their spatial patterns, confirmed the large impact of groundwater on surface water chemistry, especially in the polders that have high seepage rates. Our analysis indicates that the elevated nutrient and bicarbonate concentrations in the groundwater seepage originate from the decomposition of organic matter in subsurface sediments coupled to sulfate reduction and possibly methanogenesis. The large loads of nutrient-rich groundwater seepage into the deepest polders indirectly affect surface water quality in the surrounding area, because excess water from the deep polders is pumped out and used to supply water to the surrounding infiltrating polders in dry periods. The study shows the importance of the connection between groundwater and surface water nutrient chemistry in the greater Amsterdam area. We expect that taking account of groundwater-surface water interaction is also important in other subsiding and urbanising deltas around the world, where water is managed intensively in order to enable agricultural productivity and achieve water-sustainable cities.

\section{Introduction}

The hydrology of many lowland delta areas is highly manipulated by human activities such as ditching, draining, and embanking, to enable agriculture and habitation. Lowland 
deltas account for $2 \%$ of the world's land, but accommodated around 600 million people in 2000, and will accommodate about 1400 million by 2060, as was estimated by Neumann et al. (2015). The reclamation of swamps and lakes and the drainage of peat areas to enable urbanisation and agriculture severely changed the hydrological, chemical, and ecological environment of these areas (Ellis et al., 2005; Yan et al., 2017). Lowland delta areas are vulnerable for water quality deterioration by processes like salinisation and eutrophication, which can be amplified by climate change (Wu et al., 2015) and land subsidence (Minderhoud et al., 2017).

The Netherlands is a densely populated country where surface water salinisation and eutrophication are common problems. It is a typical highly urbanised country, with twothirds of its land lying below mean sea level. In the Netherlands, small regulated catchments called polders have been developed over centuries by diking in and draining lakes and swamps (Huisman, 1998). Over 10 million people are living in the coastal area, mainly in the western part where a Holocene layer of peat and clay covers Pleistocene fluvioglacial sands. The deepest polders, in particular, receive large amounts of groundwater seepage. The surface water levels within the polder catchments are artificially controlled by pumping water out into the regional water systems (called boezem), which further accelerates groundwater seepage. Some of the deep polders exhibit "upconing" of deep saline groundwater into the surface water. The salt loading towards these polders is expected to increase, mainly due to the further lowering of surface water levels in response to subsidence (e.g. Oude Essink et al., 2010; Delsman et al., 2014). Draining the peat polders has also led to subsidence and repetitive lowering of surface water and groundwater levels. As a consequence, nutrients are released due to peat oxidation (Hellmann and Vermaat, 2012). Another nutrient source is the large-scale agricultural application of manure and fertiliser. Although manure legislation was enforced in 1986, surface water quality in the area still does not meet the EU Water Framework Directive standards for chemical and ecological water quality (Rozemeijer et al., 2014). The local water authority, called Waternet, is commissioned to improve water quality in a cost-effective mitigation program. The assessment of load contributions from different pollution sources is essential to set realistic region-specific water quality targets and to select appropriate mitigation options.

Influences of groundwater on surface water quality have recently gained more attention from hydrologists (e.g. Rozemeijer and Broers, 2007; De Louw et al., 2010; Garrett et al., 2012; Delsman et al., 2015). Rozemeijer et al. (2010) found that groundwater seepage has large impacts on surface water quality in a lowland agricultural catchment. A study by Holman et al. (2008) in the United Kingdom and the Republic of Ireland also suggested that the groundwater contribution to surface water nutrient concentrations is more important than previously thought. Furthermore, Meinikmann et al. (2015) found that lacustrine groundwater discharge contributed for more than $50 \%$ of the overall external P load in their study lake. Vermonden et al. (2009) concluded that upward seepage from the Meuse-Waal canal delivered $\mathrm{NO}_{3}$ and $\mathrm{Cl}$ to urban surface water system. The impact of other landscape characteristics on surface water quality, such as soil type and land use, has also been explored. For example, Van Beek et al. (2007) found that nutrient-rich peat layers will remain a potential source of nutrients in surface water in many peat polders in the western part of the Netherlands. Mourad and van der Perk (2009) found that the spatial patterns of nitrate and phosphate concentrations in the Ahja River catchment in Estonia were related to spatial differences in urban and agricultural land use proportions. Vermaat et al. (2010) studied 13 peat polders in the Netherlands and reported that agricultural land use largely determined the variability in nutrient concentrations and loads. Phosphorus was observed in higher concentrations in urban areas than in rural areas by Meinikmann et al. (2015). In some studies, point sources like effluent from sewage treatment plants dominated the phosphorus loads (e.g. Wade et al., 2012), but the Netherlands is known to have early invested in centralised sewage treatment works, thus avoiding the many individual spills that are present is some bordering countries (EU, 2017).

Previous water quality research in polder area has mainly focused on the impact of land use types and topography. The impact of groundwater and flow routes on spatial water quality patterns in polders has not been systematically studied. Such insight is highly needed, as a cost-effective protection and regulation of water resources requires an integrated assessment of water and contaminant flow routes in the water system as a whole. In general, however, water and contaminant flow routes in urban settings are more complex than in rural areas, due to the highly variable surface permeability and human emissions of pollutants.

This study aimed at identifying the impact of groundwater on surface water quality in the polder catchments of the greater Amsterdam city area, which is the management area of Waternet, the organisation which manages dikes, regulates water levels and pumping regimes, and is responsible for the clean surface water, drinking water supply, and waste water treatment. To achieve this, we analysed regional surface water and groundwater quality monitoring data in combination with 10 landscape characteristic variables for 144 polders: nitrogen $(\mathrm{N})$ and phosphorus $(\mathrm{P})$ agricultural inputs, surface elevation, paved area percentage, surface water percentage, seepage rate, and soil type represented by calcite, humus, and clay percentages. Our statistical analyses yielded insight into the impact of groundwater on the surface water chemistry of the urban and rural polders of Amsterdam. The presented approach contributes to realistic and effective water quality regulation in the Waternet management area and can also be applied to other deltas in the world with adequate groundwater and surface water monitoring data. 

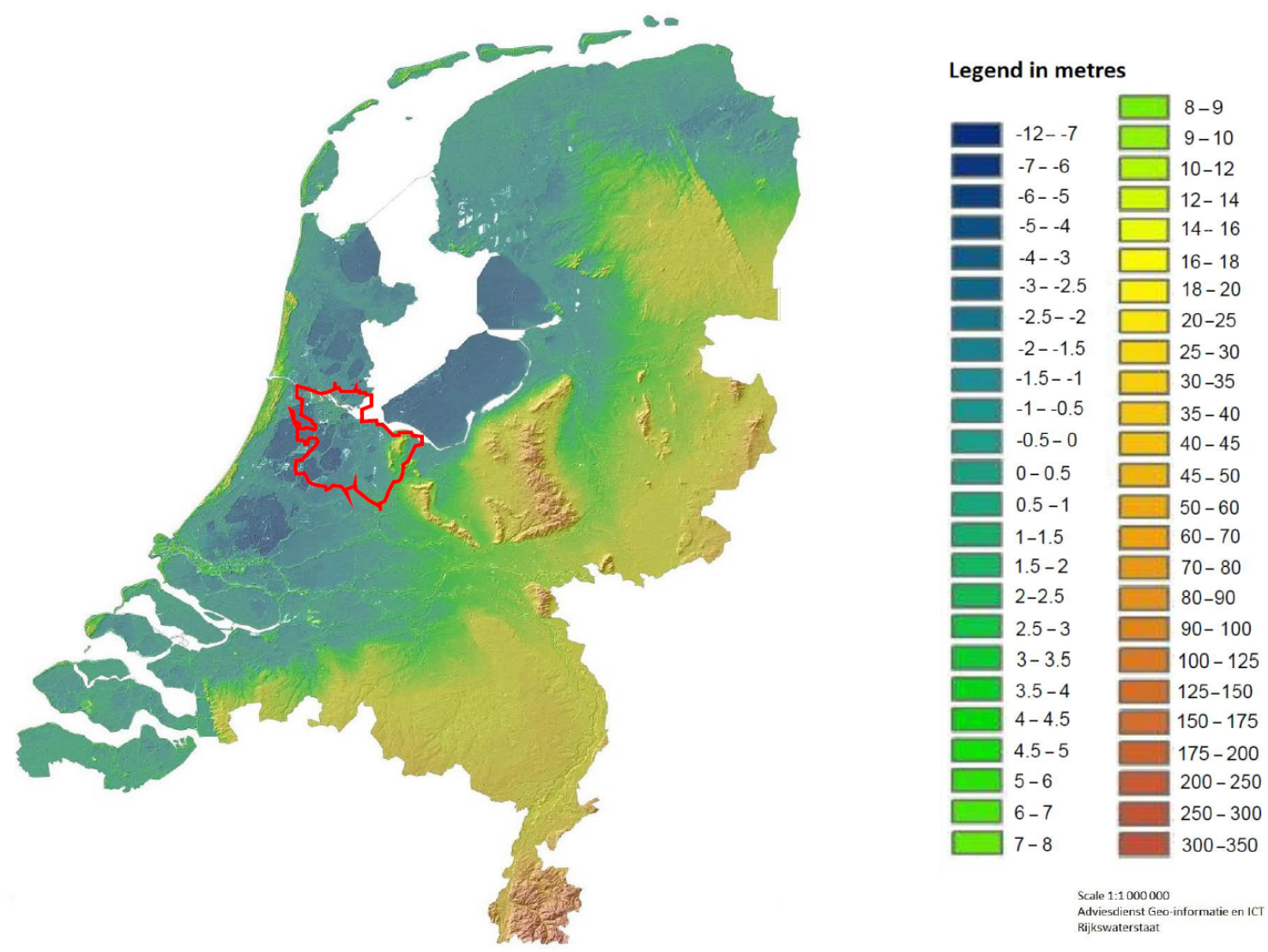

Figure 1. Location of the research area (red) projected on the elevation map of the Netherlands (elevations in metres above mean sea level).

\section{Methods}

\subsection{Study area}

This study focuses on the polder catchment landscape around the city of Amsterdam in the Netherlands. The whole study area spans $700 \mathrm{~km}^{2}$, from downtown Amsterdam situated in the northwest to the border of the province of Utrecht in the southeast (Fig. 1). Amsterdam is a low-lying highly paved city located in the western part of the Netherlands, developed around the levees of the tidal outlet of the Amstel River about 700 years ago (Vos, 2015). Nowadays, the water system in Amsterdam is connected to the large freshwater body of the Lake IJ (Fig. 1). Besides Lake IJ, other important large water bodies are the Amstel and Vecht rivers and the AmsterdamRhine Canal (ARC). This regional water system, also called the boezem, connects the Amsterdam-area water system to the Rhine River (upstream) and the Lake IJssel and the North Sea (downstream). In the 19th and 20th centuries, the city expanded, and many new neighbourhoods and suburbs were built. Polders and reclaimed lakes form the main landscape in the southward extensions of the city. Some of these polders are at several metres below mean sea level and are influenced by groundwater seepage.

\subsubsection{Landscape history and hydrology}

\section{Landscape history}

Our study area is located in the western part of the Netherlands, where large rivers and the sea have intensively interacted for millions of years. The main topographic feature is a Pleistocene sandy ice-pushed ridge with elevations ranging from 0 to $30 \mathrm{~m}$, which is located in the eastern part of the study area (Figs. 1, S1 in the Supplement). To the west, the ridge is bordered by the broad periglacial Pleistocene river plains of the Rhine delta. During the Holocene, these sandy river plains were covered with peat and clay, which are currently found at the surface throughout the western part of the Netherlands, on top of Pleistocene sands. The average thickness of the Holocene peat and clay cover is $20 \mathrm{~m}$, although it increases to over $50 \mathrm{~m}$ in former tidal inlet channels (Hijma, 2009).

In $1000 \mathrm{AD}$, about 5000 years after first settlers appeared in these lowlands, the inhabitants started mining peat, digging ditches, constructing dikes, reclaiming former swamps and lakes, and pumping water out into a large-scale drainage system (called boezem). Special hydrological catchments called polders were formed, connected by the boezem main waterways around them. Figure S1 and Table S1 in the Sup- 
plement show the entire system of polder catchments (indicated by numbers for reference) and boezems studied in this paper. Prominent on these maps are two deep polders, Horstermeer (no. 79) and Groot Mijdrecht (no. 80), two former lakes that were formed after peat excavations. Drainage for lake reclamation and groundwater extraction (Schot and Molenaar, 1992) caused further subsidence and increased seepage of paleo-marine brackish groundwater from deep aquifers (Delsman et al., 2014).

The long history of marine influence stopped after closing off the estuaries and the inland sea in the 20th century (Huisman et al., 1998). In 1932, the construction of the Closure Dike (Afsluitdijk) created the freshwater Lake IJssel out of the former saltwater Zuider Zee ("Southern Sea") to protect the surroundings from floods and to enable land reclamation. The former marine impact is still reflected by the presence of brackish groundwater in the shallow subsurface (Schot and van der Wal, 1992).

The construction of the Amsterdam-Rhine Canal separated the study area into two parts (Fig. S1): central Holland in the west and the Vecht lakes area in the east. In the central Holland polders, relatively thick peat layers and pyrite-rich clays are still present in the shallow subsoil, as described by Van Wallenburg (1975). The Vecht lakes area is characterized by large open-water areas and a number of wetland nature reserves. The rest of the Vecht lakes area is mainly grassland used for dairy farming. Soils in this area are generally wet and rich in organic matter and clay (Schot and van der Wal, 1992).

Mainly during the 20th century, the urban areas have been growing from the historic city centres on river and tidal channel levees into the surrounding low-lying polders. To facilitate the construction of buildings, a $1-5 \mathrm{~m}$ thick layer of sand was often supplied on top of the original sediments. The thickness of this suppletion sand layer is extremely variable even on a small scale. The sand suppletions are either calcite-poor without shell fragments or calcite-rich with shell fragments that indicate their (peri-) marine origin. The spatial distribution and sources of the sand suppletions probably influence groundwater and surface water chemistry, but are poorly registered.

\section{Polder hydrology}

Within the polders, the water levels are artificially maintained between fixed boundary levels to optimise conditions for their urban or agricultural land use. Boezem water levels always exceed the polder surface water levels. In the case of water deficiency, water is let into the polder ditches from the boezem through pipes by gravity flow (Fig. 2a). Pumping stations are situated at the boezems to regulate the water levels in the polders in times of precipitation excess. In the case of a water surplus, pumping stations start pumping water out of the polder into the boezem system (Fig. 2b).
The regional flow directions in wet and dry periods in the study area are depicted in Fig. 3. The Amsterdam-Rhine Canal, the Amstel River, and the Vecht River are the main water courses discharging surface water from the south to the north in periods of water surplus (Fig. 3). In periods of water deficiency, however, the flow directions are reversed in some parts of the system.

There are six main sources of inlet water to compensate for water shortage in dry periods (Fig. 3): (1) AmsterdamRhine Canal - water of the ARC originates from the Rhine and is supplied as inlet water for the southeast polders and polders in the southeast of Amsterdam city; (2) Amstel River - the historic canals of the city of Amsterdam are mainly flushed by water from the Amstel River (via the canals, this water discharges to the downstream part of the ARC and further into the North Sea); (3) Groot Mijdrecht and Horstermeer - the brackish surplus of seepage water from the deep polder, Groot Mijdrecht $\left(\sim 1000 \mathrm{mg} \mathrm{Cl} \mathrm{L}^{-1}\right.$ on average), and Horstermeer $\left(\sim 500 \mathrm{mg} \mathrm{ClL}^{-1}\right)$ is pumped into the boezem system and is redistributed towards surrounding polders (pink lines in Fig. 3); (4) Rijnland Water Authority district - polders in the far west of the study area receive inlet from the neighbouring Water Authority district Rijnland (the water quality of this source is unknown); (5) and (6) Vecht River and Lake IJ - polders along the Vecht River receive inlet water that partly originates from the Rhine and partly from Lake IJ. Polders close to Lake IJ receive large amounts of water directly from the lake. The Lake IJ water is also used to flush canals in the city of Amsterdam.

\subsubsection{Characterisation of regions}

Based on the geology and paleo-hydrological history as introduced in Sect. 2.1.1, five regions were identified (see Fig. 4). The five regions are: (1) the Zuider Zee margin region, with shallow brackish groundwater, lies directly adjacent to the former saltwater Zuider Zee, which was dammed in the 1930s and transformed into the freshwater Lake IJssel (connected to Lake IJ), which is now the biggest freshwater reservoir of the Netherlands; (2) the deep polders Groot Mijdrecht and Horstermeer, which are reclaimed lakes with clayey lake sediments at the surface. These polders are characterized by upconing of salt groundwater from deeper layers (Oude Essink et al., 2005; Delsman et al., 2014) and intensive arable farming; (3) the central Holland region, where the polders are characterized by a relatively thick sequence of marine clays and intercalated peats; (4) the Vecht lakes region at the western margin of the ice-pushed ridge, characterized by shallow peat soils over a sandy subsoil and large shallow lakes and wetlands resulting from peat excavations (van Loon, 2010), mostly used for dairy farming; and (5) the icepushed ridge in the eastern part of the study area, which is characterized by permeable sandy soils, recharge of freshly infiltrated water, and the near absence of draining water courses. 

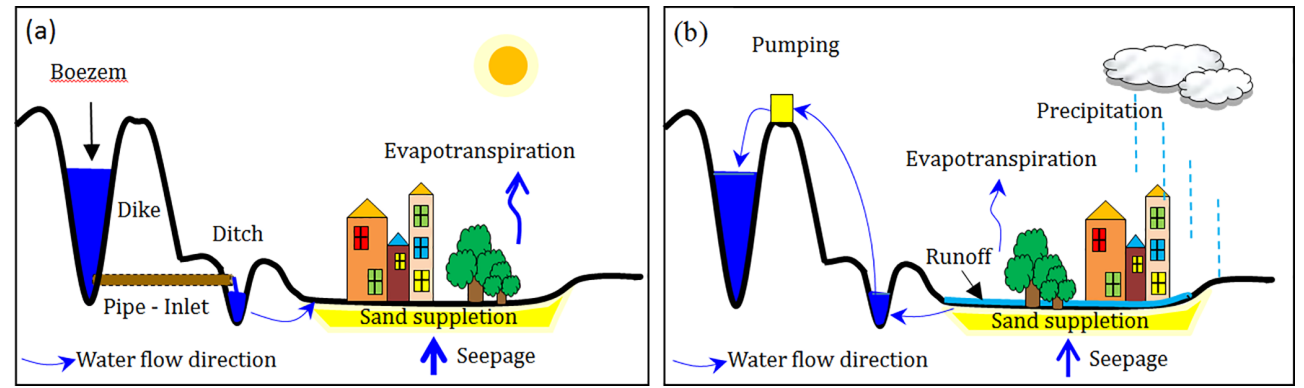

Figure 2. Conceptual model of water fluxes in a polder system in times of water deficiency (a) and surplus (b).

Our a priori expectation was that the groundwater quality of these five regions is significantly different, because of their specific paleo-hydrological situations and present-day groundwater flow patterns. We therefore used the regions to evaluate the groundwater quality patterns and to give structure to our comparisons between groundwater and surface water concentrations and loads.

\subsection{Data processing}

The database that was compiled and used for this study covers 144 individual polders and includes monthly surface water quality data, spatiotemporally averaged groundwater quality data (TN, $\mathrm{NO}_{3}, \mathrm{NH}_{4}, \mathrm{SO}_{4}, \mathrm{TP}, \mathrm{Ca}, \mathrm{HCO}_{3}$, and $\mathrm{Cl}$ ), daily pumping station discharge time series, and polder averages of the following statistic variables: $\mathrm{N}$ and $\mathrm{P}$ agricultural inputs, polder seepage rates, elevations, surface water and paved area percentages, and calcite, clay, and humus percentages of the upper soil layer. More information about the data processing and the database can be found in the Supplement.

\subsubsection{Groundwater data}

A total of 802 observation wells of groundwater quality are available from the period 1910-2013 (mostly after 1980), largely drawn from the National Groundwater Database DINO (TNO, DINOloket, 2016). We selected analyses from the upper $50 \mathrm{~m}$ of the subsurface, which corresponds with the thickness of the first main Pleistocene aquifer in the area and the Holocene cover layer. For our analyses, in order to use as much of the available groundwater data as possible to cover the entire region and all the polders, we averaged concentrations at individual monitoring screens of each monitoring well for all sampling dates available. The large majority of the groundwater quality data we used is from the last 30 years (for example, $85 \%$ of the chloride and $93 \%$ of the $\mathrm{P}$ measurements are from after 1980). In this study area, we do not expect that using some data from before 1980 would create a significant bias to the results of the study, because hydrogeochemical processes in the reactive subsurface such as sulfate reduction and methanogenesis have a stabilising effect on the water composition in this area. Moreover, the overall flow patterns have not changed much in the past 30 to 100 years, because the flow systems are completely determined by the water levels maintained in the polder systems which have not changed much over the past 100 years. However, the interface between freshwater and saltwater is known to slowly move into the direction of a new equilibrium (Oude Essink et al., 2010), but the process is known to be very slow and to continue over the next 200 years.

To analyse the spatial pattern of groundwater quality, we averaged concentrations of all the monitoring wells located in the same polder (for more details, see Table S2). For 24 polders out of the polders without groundwater quality data, the concentrations were estimated by inverse distanceweighted interpolation, however, using absolute elevation difference instead of distance. The greater the absolute elevation difference, the less influence the polder has on the output value. The equations are as follows:

$C_{0}=\sum_{i=1}^{n} \lambda_{i} C_{i}$

$\lambda_{i}=d_{i_{0}}^{-p} / \sum_{i=1}^{n} d_{i_{0}}^{-p}, \sum_{i=1}^{n} \lambda_{i}=1$,

where $C_{0}$ is the prediction of target polder, $C_{i}$ is the observed value of surrounding polders, $n$ is the number of observations, $p$ is the power parameter ( 2 in this case), and $d_{i_{0}}$ is the absolute elevation differences of target polder with surrounding polders. Subsequently, to interpret the groundwater quality patterns, the variation of concentrations in and between the five regions was visualised using box plots (Helsel and Hirsch, 2002).

Because our dataset contains both freshwater and brackish to saline water, we used the mass $\mathrm{SO}_{4} / \mathrm{Cl}$ ratio of the samples as an indicator of sulfate reduction. $\mathrm{SO}_{4} / \mathrm{Cl}$ ratios lower than the seawater ratio of 0.14 (Morris and Riley, 1966) point to the occurrence of sulfate reduction (Appelo and Postma, 2005; Griffioen et al., 2013). Ratios above 0.14 point to the addition of sulfate relative to diluted seawater through processes like pyrite $\left(\mathrm{FeS}_{2}\right)$ oxidation or through input via atmospheric inputs, fertilisers, manure, or leakage and overflow of sewer systems. 

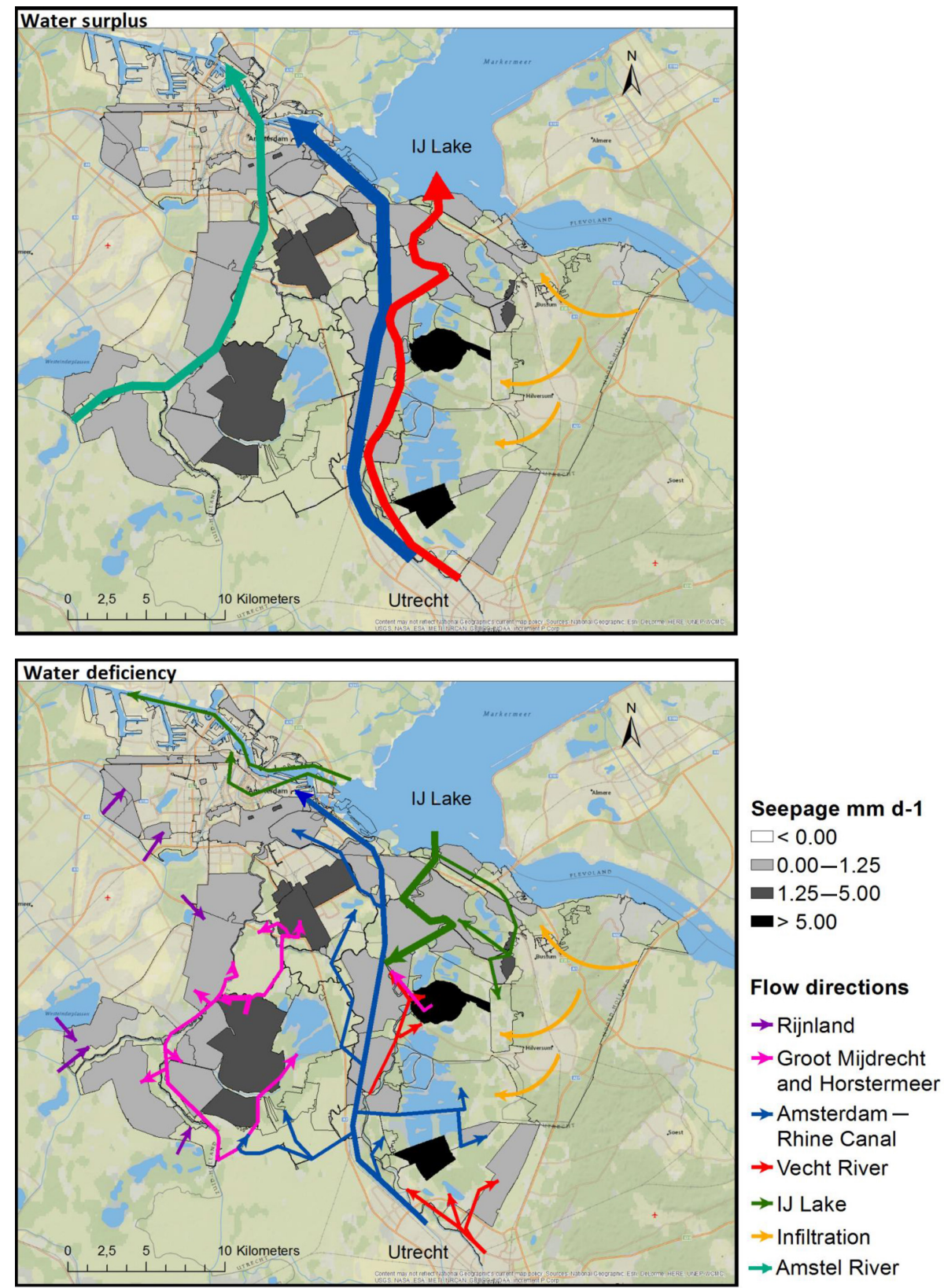

Figure 3. Flow directions of surface water in water surplus and water deficiency period. "Rijnland" refers to the management area of the Rijnland Authority.

Average concentrations in groundwater for each polder were mapped to be compared with average annual surface water concentrations (see Sect. 2.2.2). The potential relationship between the solute concentrations in groundwater (TN, $\mathrm{NO}_{3}, \mathrm{NH}_{4}, \mathrm{SO}_{4}, \mathrm{TP}, \mathrm{Ca}, \mathrm{HCO}_{3}$, and $\mathrm{Cl}$ ), the $\mathrm{N}$ and $\mathrm{P}$ agricultural inputs, and the landscape variables (paved area percentage, elevation, seepage rate, surface water area percentage, lutum, humus, and calcite percentages of top soil) were explored using the Spearman correlation, which reduces the influence of outliers and yields a robust correlation statistic (Helsel and Hirsch, 2002).
To further explore the statistical relations in our dataset, box and scatter plots were made to evaluate $\mathrm{HCO}_{3}, \mathrm{SO}_{4}$, $\mathrm{Cl}$, and nutrient (TN, $\mathrm{NO}_{3}, \mathrm{NH}_{4}$, and $\mathrm{TP}$ ) concentrations in groundwater. We also explored the links between alkalinity (over $99 \%$ of our groundwater alkalinity was dominated by $\mathrm{HCO}_{3}$, Stuyfzand and Stuurman, 2006), $\mathrm{Cl}$ concentration, $\mathrm{SO}_{4} / \mathrm{Cl}$ ratio, and nutrients $\left(\mathrm{NH}_{4}\right.$ and $\left.\mathrm{TP}\right)$ concentrations. For our interpretation, we also used the calculated amount of consumed or produced $\mathrm{SO}_{4}\left(\mathrm{mg} \mathrm{L}^{-1}\right)$ relative to the $\mathrm{SO}_{4} / \mathrm{Cl}$ 


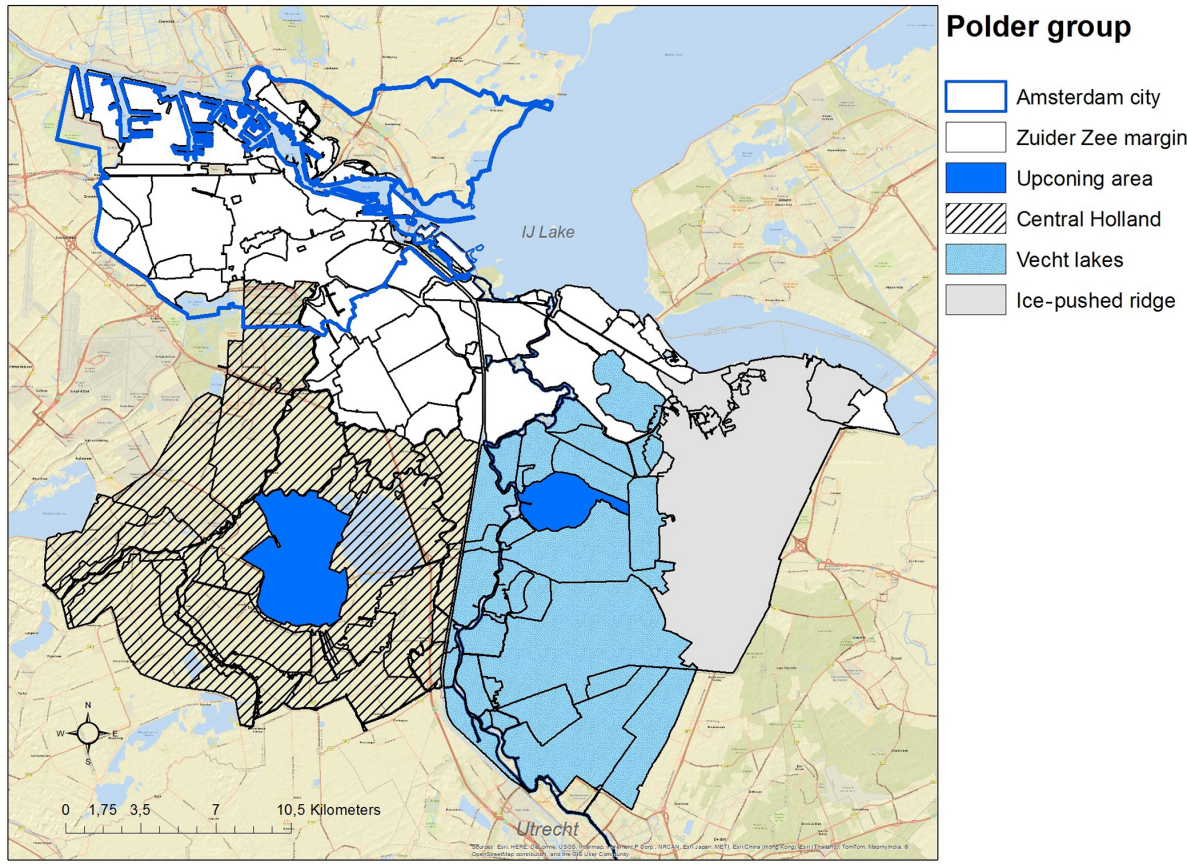

Figure 4. Regions of the study area: (1) Zuider Zee margin, (2) upconing area (deep brackish seepage polders, Groot Mijdrecht and Horstermeer), (3) central Holland, (4) Vecht lakes and (5) ice-pushed ridge. The Amsterdam city area is circled by the blue line.

ratio of diluted seawater, using Eq. (3).

$$
\begin{aligned}
& \mathrm{SO}_{4 \text { consumed(-) or produced(+) }} \\
& \quad=\mathrm{SO}_{4 \text { measured }}-\mathrm{Cl}_{\text {measured }} \cdot \mathrm{SO}_{4 \text { sea }} / \mathrm{Cl}_{\text {sea }}
\end{aligned}
$$

In order to understand the impact of cation exchange processes involving $\mathrm{Ca}$ and $\mathrm{Na}$ exchange during salinisation and/or freshening of aquifers (Griffioen, 1994) we defined the amount of exchange $\mathrm{Na}_{\mathrm{ex}}$ as follows:

$\mathrm{Na}_{\mathrm{ex}}=\mathrm{Na}_{\mathrm{gw}}-\mathrm{Cl}_{\mathrm{gw}}\left(\mathrm{Na}_{\mathrm{gw}} / \mathrm{Cl}_{\mathrm{seaw}}\right)$

where $\mathrm{Na}_{\mathrm{ex}}$ is the amount of $\mathrm{Na}$ exchange, gw is groundwater, and seaw is seawater. $\mathrm{Na}_{\mathrm{ex}}>1$ points to freshening, $\mathrm{Na}_{\mathrm{ex}}<-1$ to salinising conditions.

\subsubsection{Surface water data}

Loads represent the contribution of polders to surface water quality of the regional water system in weight per time unit. To eliminate the impact of the size of polders, we calculated daily load per area in kilograms per hectare per day $\left(\mathrm{kg} \mathrm{ha}^{-1} \mathrm{~d}^{-1}\right)$. This was calculated using the daily average loads of each solute divided by the polder areas using Eq. (5):

load per area $=\frac{L}{A}=\frac{1}{A} \cdot \frac{C \cdot Q}{1000}$,

where $L$ is daily load $\left(\mathrm{kg} \mathrm{d}^{-1}\right), A$ is polder area (ha), $C$ is daily solute concentration $\left(\mathrm{mg} \mathrm{L}^{-1}\right)$ and $Q$ is daily discharge $\left(\mathrm{m}^{3} \mathrm{~d}^{-1}\right)$. Average daily loads for each year were multiplied by 365 to get average yearly loads per area. Monthly surface water quality measurements for the period 2006-2013 of 144 polders were extracted from the Waternet database. The measurements were converted to daily time series by stepwise interpolation between the monthly measurements. We assigned a concentration of zero to measurements below the detection limits. Discharge data $Q$ are daily measurements over the same time period. An average over multiple pumps, when present, was taken for each polder. For further details about the data processing we refer to Table S2.

The pumping discharge is regulated to respond to water surplus or deficiency conditions in the polder catchments. Using the pumping frequency data, we proved that solute concentrations in pumped water are usually higher at the beginning of each pumping activity (van der Grift et al., 2016). The pumping rates may also influence water quality in the polder. To eliminate differences caused by pumping rates, we used the normalised concentration calculated using Eq. (6).

$C=\frac{\text { load per area } \cdot A}{Q}$

In this equation, $C$ is the normalised concentration $\left(\mathrm{mg} \mathrm{L}^{-1}\right)$, load per area is from Eq. (5), $Q$ is the pumping discharge $\left(\mathrm{m}^{3} \mathrm{yr}^{-1}\right)$, and $\mathrm{A}$ is the polder area $\left(\mathrm{m}^{2}\right)$. The statistical methods that were used for groundwater quality (described in Sect. 2.2.1) were also applied to the surface water normalised concentrations.

Based on a national assessment on ecosystem vulnerability, environmental quality standards (EQSs) were set by the 
Water Boards (Heinis and Evers, 2007). For most ditches and channels in the clay and peat regions, EQSs of TN and TP are 2.4 and $0.15 \mathrm{mg} \mathrm{L}^{-1}$, respectively (Rozemeijer et al., 2014). We used these most common EQSs as reference concentration values. For example, the EQSs of TN and TP were used for the legend classifications in our groundwater and surface water quality maps and were added as reference lines in our concentration box plots. The percentages of polders that exceeded these standards were calculated in this paper.

\subsubsection{Surface water compared with groundwater solute concentrations}

We statistically analysed the groundwater and surface water quality data and landscape characteristic variables by (1) calculating the correlation coefficients between averaged groundwater solute concentrations and normalised concentrations of surface water using the Spearman method, and (2) by selecting variables (based on the correlation matrix above) to be integrated into multiple linear regression models for predicting surface water solute concentrations. Again, the Spearman method was applied and linear regression was based on ranks in order to avoid outliers to determine the outcomes. The explaining variables for surface water concentrations include groundwater solute concentrations, $\mathrm{N}$ and $\mathrm{P}$ agricultural inputs, landscape characteristics, and the $\mathrm{SO}_{4} / \mathrm{Cl}$ ratio in groundwater. We adopted the method described by Rozemeijer et al. (2010), who described a form of sequential multiple regression analysis, where variables were added to the regression depending on their effects on the coefficient of determination, $R^{2}$. The regression analysis started with a singular regression using the explaining variable with the highest coefficient of determination $\left(R^{2}\right)$ for explaining the surface water quality parameter under consideration. Subsequently, the best regression models were searched with two and three explaining variables, and we accepted an additional variable only when the coefficient of determination $R^{2}$ increased by least 0.03 . In this method, dependent variables can still add to the resulting $R^{2}$ as the coefficient of determination $R^{2}$ of the individual dependent variable pair is seldom larger than 0.7 , suggesting that some explaining power may still be present in the uncorrelated part (0.3). For comparison purposes, we also used the surface water EQSs as reference concentration values in the groundwater quality maps and box plots, although the EQSs have no administrative meaning for groundwater itself.

\subsubsection{Solutes redistribution in surface water}

Loads were used to assess the impact of different polders as sources of solutes for the boezems and the receiving water bodies further downstream. In general, the spatial patterns can be distinguished through maps of the surface water solute loads per area if there are no other influences. However, there are exceptions, such as the seepage water which is pumped out of the two upconing polders Groot Mijdrecht and Horstermeer, which is discharged into the boezem system and used as inlet water for the surrounding polders during summer. To show the impact of this inlet water on the receiving polders' water quality, we analysed the inlet solute loads and the resulting surface water concentrations for the Botshol polder. The Botshol polder (part of polder no. 104 Noorderpolder of Botshol, south and west) with an area of $1.3 \mathrm{~km}^{2}$ receives inlet water from the Amstel boezem system that has a significant contribution of seepage water that is pumped out of the Groot Mijdrecht polder.

Two models were applied for simple solute concentration calculations based on inlet water quality. Model 1 calculates the accumulation of solutes in the water body, with evaporation as the only output for water (leaving the solutes behind). Model 2 models the complete mixing and outlet of both water and solutes via other routes like the outlet weir, infiltration, and leakage. In reality, water leaves the Botshol polder partly via evaporation (Model 1) and partly via other routes (Model 2):

Model 1 (evaporation),

$C_{i+1}=\left(C_{i} \cdot V_{0}+C_{\text {inlet }} \cdot Q_{\text {inlet }}\right) / V_{0}$,

and Model 2 (infiltration/outlet),

$C_{i+1}=\left(C_{i} \cdot V_{0}+C_{\text {inlet }} \cdot Q_{\text {inlet }}\right) /\left(V_{0}+Q_{\text {inlet }}\right)$,

where $C_{i+1}$ is the predicted solute concentration after getting inlet water at time $i ; C_{i}$ is the predicted solute concentration in the polder at time $i$; the outlet measurements in the beginning of wet period were taken as $C_{0} ; V_{0}$ is the water volume in the polder $\left(800000 \mathrm{~m}^{3}\right)$, which is assumed to be constant as water levels are tightly controlled; $C_{\text {inlet }}$ is the estimated $\mathrm{Cl}$ concentration in the inlet water $\left(1000 \mathrm{mg} \mathrm{L}^{-1}\right)$; and $Q_{\text {inlet }}$ is estimated constant inlet water volume, $6000 \mathrm{~m}^{3} \mathrm{~d}^{-1}$. All parameters are shown in supplementary information Excel spreadsheets. The models were applied in the year 2006, 2008, 2009, 2010, 2011, and 2012.

\section{Results}

\subsection{Spatial pattern and statistical analysis of groundwater quality}

Figures 5 and 6 show the groundwater quality for the upper main aquifer under the 144 polders for $\mathrm{Cl}, \mathrm{Ca}, \mathrm{HCO}_{3}, \mathrm{SO}_{4}$, $\mathrm{TN}, \mathrm{NH}_{4}, \mathrm{NO}_{3}$, and TP. The relations between groundwater solutes, landscape variables, and potential hydrochemical reactions in the subsurface were explored by correlation analysis, the results of which are shown in Table 1 and Figs. 7 and 8 .

\subsubsection{Cl, $\mathrm{Ca}$, and $\mathrm{HCO}_{3}$}

In Fig. 5, the Zuider Zee margin, where brackish groundwater is dominant, P25 and P75 of concentrations are between 


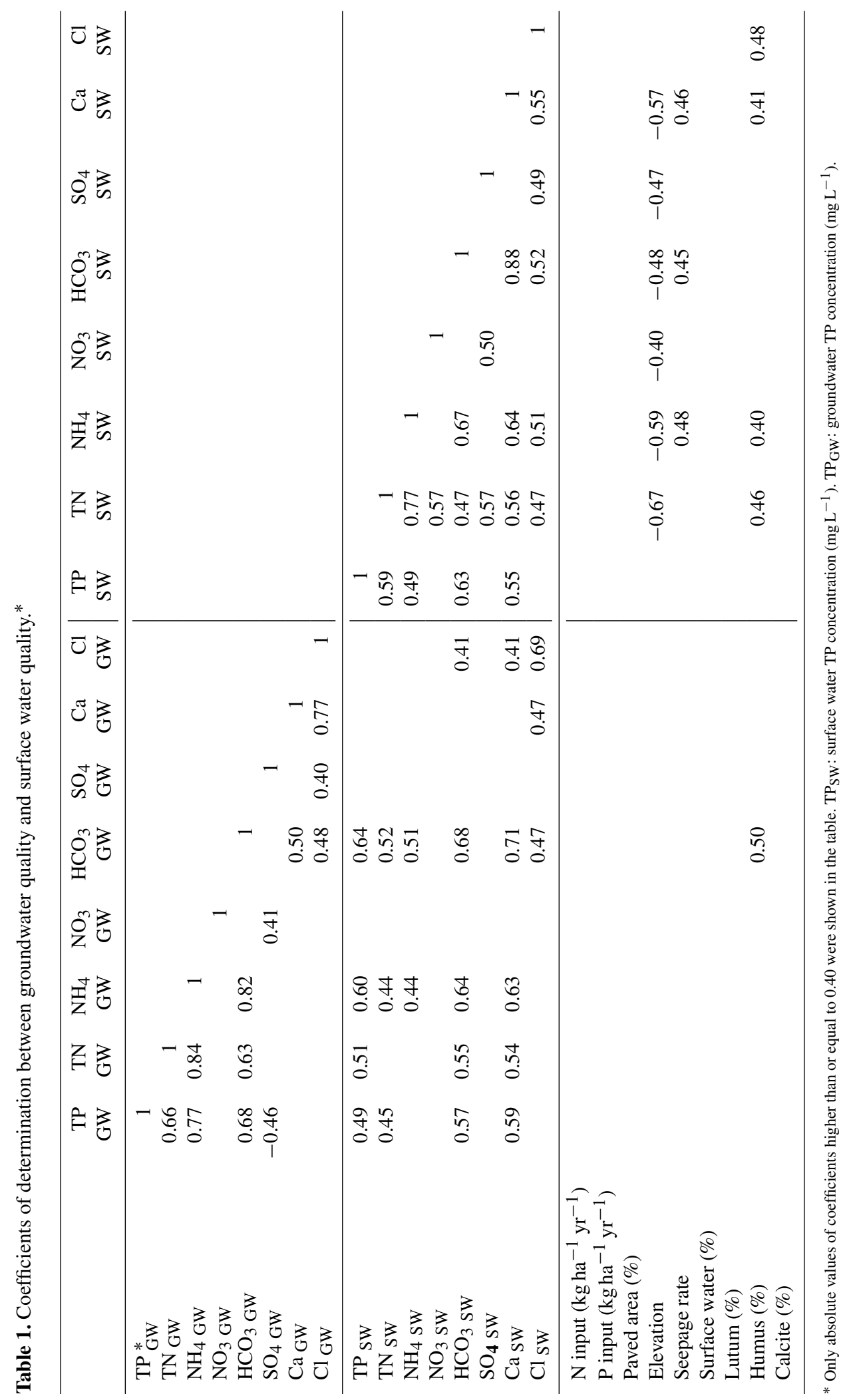



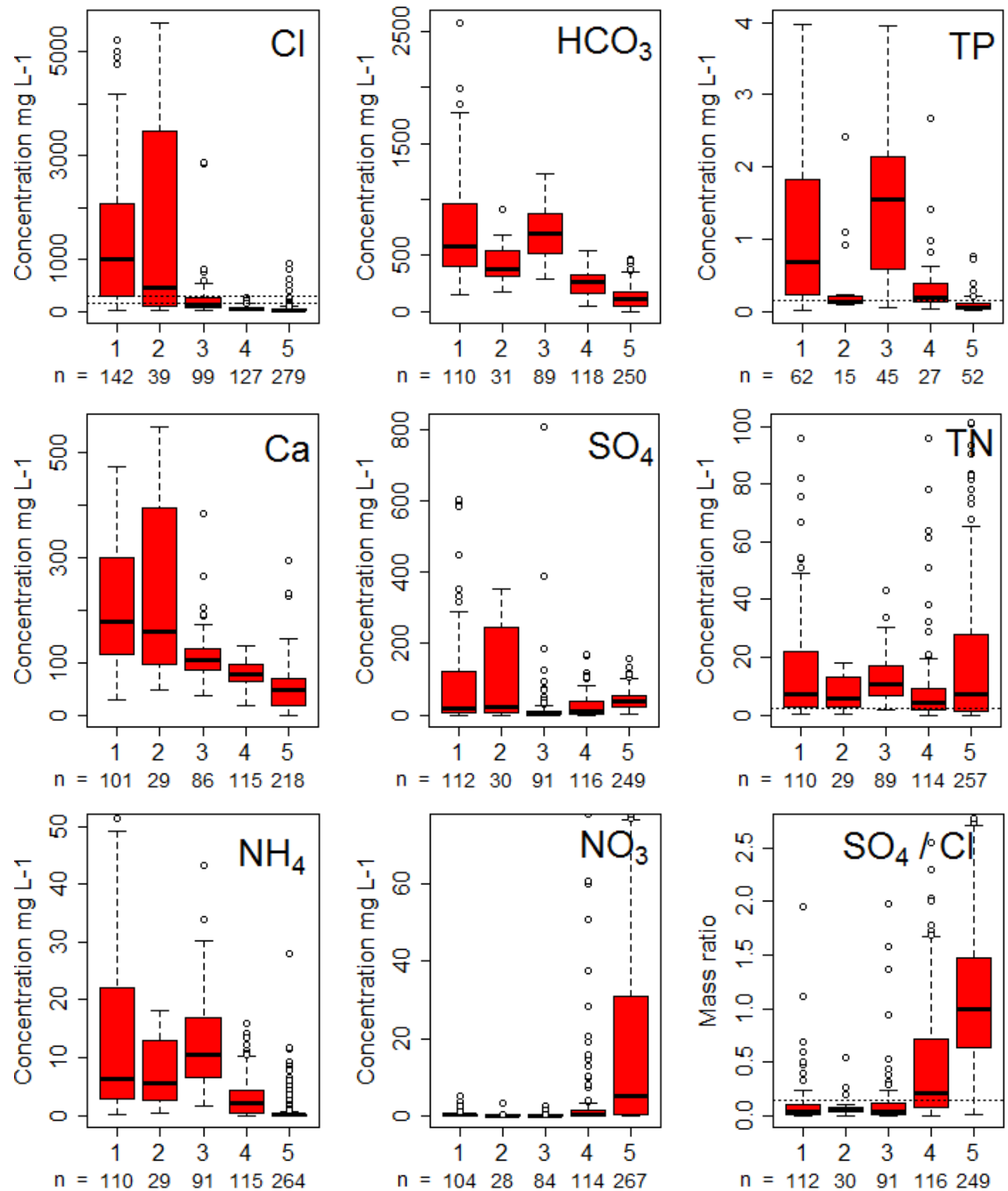

Figure 5. Spatial variation of groundwater quality. (1) Zuider Zee margin, (2) upconing area (Groot Mijdrecht and Horstermeer), (3) central Holland, (4) Vecht lakes, (5) ice-pushed ridge (see Fig. 4). The amount of available data of each group is denoted by $n$. Box plots show the distribution of solutes in the five regions. The two horizontal dashed lines for $\mathrm{Cl}$ indicate freshwater $\left(<150 \mathrm{mg} \mathrm{L}^{-1}\right)$ and brackish water $\left(>300 \mathrm{mg} \mathrm{L}^{-1}\right)$, respectively. Dashed lines represent EQSs for TN $\left(2.4 \mathrm{mg} \mathrm{L}^{-1}\right)$ and TP $\left(0.15 \mathrm{mg} \mathrm{L}^{-1}\right)$. The dashed line in the $\mathrm{SO}_{4} / \mathrm{Cl}$ plot indicates the mass ratio of 0.14 in seawater $(<0.14$ indicates sulfate reduction; $>0.14$ indicates additional sources of sulfate besides (diluted) seawater). Part of the outliers of TP, $\mathrm{TN}, \mathrm{NH}_{4} \mathrm{NO}_{3}$, and $\mathrm{SO}_{4} / \mathrm{Cl}$ fell out of the ranges in the figures.

290 and $2100 \mathrm{mg} \mathrm{L}^{-1} \mathrm{Cl}$, between 100 and $300 \mathrm{mg} \mathrm{L}^{-1} \mathrm{Ca}$, and between 400 and $1000 \mathrm{mg} \mathrm{L}^{-1} \mathrm{HCO}_{3}$. Relatively high concentrations of $\mathrm{Cl}, \mathrm{Ca}$, and $\mathrm{HCO}_{3}$ were also found for the two deep polders, Groot Mijdrecht and Horstermeer (upconing area), with known upconing of salt groundwater. The central Holland area was dominated by fresh groundwater with low $\mathrm{Cl}$ and $\mathrm{Ca}$ concentrations, but with considerable amounts of $\mathrm{HCO}_{3}$. Polders with relatively high chloride $\left(>1000 \mathrm{mg} \mathrm{L}^{-1}\right)$ are distributed along the former
Zuider Zee margin, plus the upconing area which is two deep polders with known upconing of brackish water. Relative to the regions above, the Vecht lakes area and the ice-pushed ridge showed significantly less mineralised waters with lower $\mathrm{HCO}_{3}$ and $\mathrm{Cl}$ concentrations. For example, the $\mathrm{P} 75 \mathrm{~s}$ of $\mathrm{Cl}$ in these two regions are below $150 \mathrm{mg} \mathrm{L}^{-1}$ and the $\mathrm{P} 75 \mathrm{~s}$ of $\mathrm{HCO}_{3}$ are below $350 \mathrm{mg} \mathrm{L}^{-1}$. The groundwater $\mathrm{HCO}_{3}$ concentrations (Fig. 6) show an increasing east-west trend with 

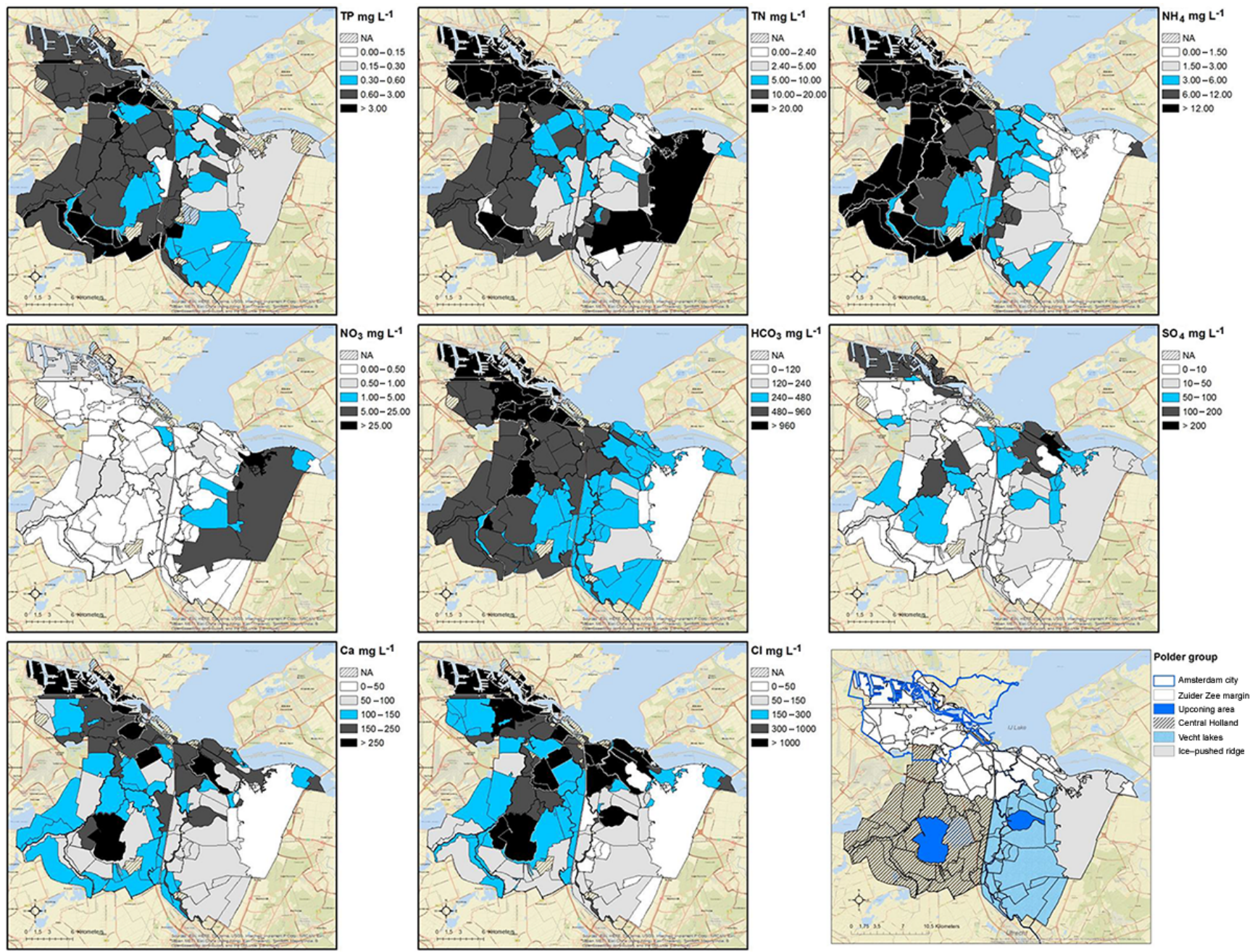

Figure 6. Average groundwater concentrations $\left(\mathrm{mg} \mathrm{L}^{-1}\right)$ per polder.

the highest concentrations in both the fresh and brackish areas west of the Amsterdam-Rhine Canal.

\subsection{2 $\mathrm{SO}_{4}$ and $\mathrm{SO}_{4} / \mathrm{Cl}$}

The Zuider Zee margin and the upconing area showed large ranges of $\mathrm{SO}_{4}$ concentrations (P25 and P75: 7-125 and 7$250 \mathrm{mg} \mathrm{L}^{-1}$, respectively) with the $\mathrm{SO}_{4} / \mathrm{Cl}$ mass ratios generally lower than the 0.14 ratio for diluted seawater. The polders in the eastern Zuider Zee margin showed the highest average $\mathrm{SO}_{4}$ levels (Fig. 6). The central Holland area exhibited the lowest $\mathrm{SO}_{4}$ concentrations with the smallest variability, with $\mathrm{SO}_{4} / \mathrm{Cl} \mathrm{P} 75$ typically lower than 0.14 . However, some outliers in this region reached quite high sulfate concentration levels $\left(>200 \mathrm{mg} \mathrm{L}^{-1}\right)$. The Vecht lakes and the ice-pushed ridge showed intermediate sulfate concentrations and typically have a $\mathrm{SO}_{4} / \mathrm{Cl}$ ratio clearly above 0.14 .

\subsection{3 $\mathrm{NH}_{4}, \mathrm{TN}, \mathrm{NO}_{3}$, and $\mathrm{TP}$}

The higher groundwater $\mathrm{NH}_{4}$ and TP concentrations are generally located in the western part of the study area (Zuider Zee margin, upconing area, and central Holland regions). Median $\mathrm{NH}_{4}$ concentrations in the Zuider Zee margin $\left(6.4 \mathrm{mg} \mathrm{L}^{-1}\right)$ and central Holland $\left(10.6 \mathrm{mg} \mathrm{L}^{-1}\right)$ were far higher than in the Vecht lakes $\left(2.1 \mathrm{mg} \mathrm{L}^{-1}\right)$ and ice-pushed ridge regions $\left(0.07 \mathrm{mg} \mathrm{L}^{-1}\right)$. The same was observed for TP $\left(0.7,1.6,0.2\right.$, and $0.06 \mathrm{mg} \mathrm{PL}^{-1}$, respectively). Nutrient concentrations in the upconing area (medians $5.7 \mathrm{mg}$ $\mathrm{NH}_{4} \mathrm{~L}^{-1}$ and $0.14 \mathrm{mg} \mathrm{PL}^{-1}$ ) were relatively low compared with the groundwater in the Zuider Zee margin and central Holland areas, although we consider the $\mathrm{NH}_{4}$ concentration levels to be substantial given the surface water EQS of $2.4 \mathrm{mg} \mathrm{N} \mathrm{L}^{-1}$. TN showed the highest median concentration levels in the Zuider Zee margin and central Holland regions, as well as in the ice-pushed ridge $\left(7.3 \mathrm{mg} \mathrm{N} \mathrm{L}^{-1}\right)$. The icepushed ridge region also showed the highest level of $\mathrm{NO}_{3}$. In 


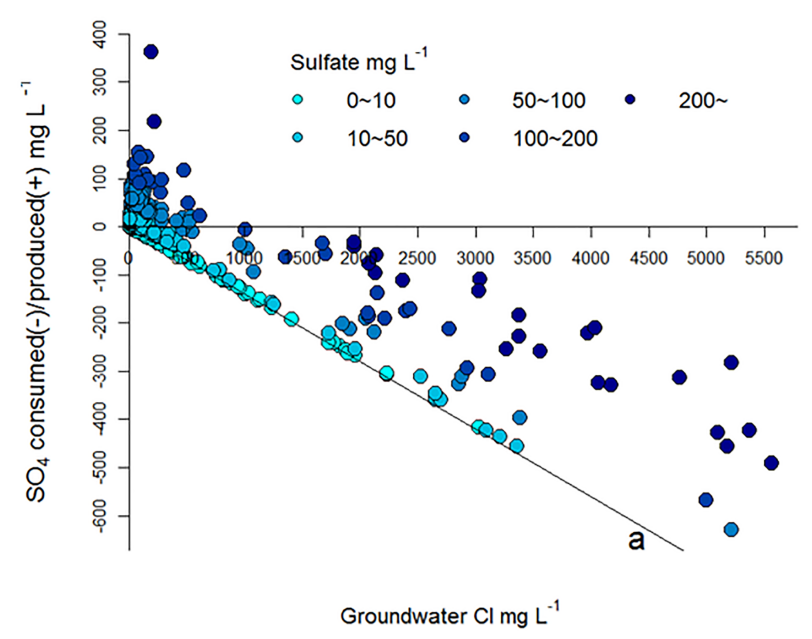

Figure 7. Calculated concentration of sulfate-reacted vs. groundwater chloride concentration. The black line, a, indicates the freshwater-seawater mixing line where sulfate reduction is complete.

the latter region, nitrate is the main component of $\mathrm{TN}$, while $\mathrm{NH}_{4}$ is the main component in the other regions.

Groundwater quality varied from fresh, low mineralised in the eastern parts (Vecht lakes and ice-pushed ridge, Fig. 4) towards brackish, highly mineralised and nutrient-rich groundwater in the northwest (Zuider Zee margin and central Holland, Fig. 4). This relationship was further indicated by the strong correlations between $\mathrm{Ca}$ and $\mathrm{Cl}$ (Spearman $R^{2}$ 0.77) and between $\mathrm{HCO}_{3}$, TP, and $\mathrm{NH}_{4}\left(R^{2} 0.68-0.82\right)$ in groundwater (Table 1). The spatial Ca pattern corresponds largely with the $\mathrm{Cl}$ pattern (Fig. 6), showing higher Ca concentrations in the brackish waters, which is related to the high $\mathrm{Ca}$ concentrations in (diluted) seawater (Sect. 4.1). The strong correlation between $\mathrm{TN}$ groundwater and $\mathrm{NH}_{4}\left(R^{2} 0.84\right)$ showed the dominance of $\mathrm{NH}_{4}$ in $\mathrm{TN}$ groundwater, except in the suboxic groundwaters under the ice-pushed ridge, where nitrate dominates $\mathrm{TN} . \mathrm{HCO}_{3}$, TP, and $\mathrm{NH}_{4}$ were all weakly negatively (absolute values of $R^{2}$ are lower than 0.40) correlated with elevation, indicating that higher concentrations exist in the deeper polders, which are more affected by brackish groundwater seepage. No significant correlation was found with agricultural $\mathrm{N}$ and $\mathrm{P}$ inputs, except for a negative correlation between groundwater $\mathrm{TN}$ concentrations and $\mathrm{N}$ input (Table S2, absolute value lower than 0.4). This suggests that non-agriculture sources of $\mathrm{N}$ dominate in most areas in general.

In the more mineralised groundwater systems, sulfate reduction is a potential cause of the significant relationship between $\mathrm{HCO}_{3}$, TP, and $\mathrm{NH}_{4}$. From using the $\mathrm{SO}_{4} / \mathrm{Cl}$ ratio of the samples and comparing them with the $\mathrm{SO}_{4} / \mathrm{Cl}$ ratio in seawater (Eq. 3), it appears that most of the brackish groundwater showed signs of sulfate reduction. Figure 7 shows that the amount of $\mathrm{SO}_{4}$ consumed in the sulfate reduction process increased with the chloride concentration of the groundwater, and that sulfate reduction was complete only in part of the groundwaters. Note that groundwater below polders with excess $\mathrm{SO}_{4}$ are all in water with $\mathrm{Cl}<1000 \mathrm{mg} \mathrm{L}^{-1}$. It follows from Fig. 8 that high $\mathrm{HCO}_{3}$, TP, and $\mathrm{NH}_{4}$ concentrations mostly occurred in groundwater with a $\mathrm{SO}_{4} / \mathrm{Cl}$ ratio lower than 0.14 , indicating sulfate reduction which induces the release of $\mathrm{N}$ and $\mathrm{P}$ from the mineralised organic matter in the subsurface and the production of alkalinity during that process. Therefore, these waters typically have increased $\mathrm{HCO}_{3}$ concentrations above $480 \mathrm{mg} \mathrm{L}^{-1}$ (Fig. $8 \mathrm{a}$ and b) and are often associated with brackish groundwater that once contained sulfate (Fig. $8 \mathrm{c}: \mathrm{Cl}>300 \mathrm{mg} \mathrm{L}^{-1}$ ). The hypothetical chemical relation between sulfate reduction $\left(\mathrm{SO}_{4}\right.$ consumed) and $\mathrm{HCO}_{3} / \mathrm{NH}_{4} / \mathrm{H}_{3} \mathrm{PO}_{4}$ production from the mineralisation of organic matter can be found in the reaction equation below (Stuyfzand and Stuurman, 2006):

$$
\begin{aligned}
2 \mathrm{SO}_{4}^{2-} & +3.5 \mathrm{CH}_{2} \mathrm{O}\left(\mathrm{NH}_{3}\right)_{x}\left(\mathrm{H}_{3} \mathrm{PO}_{4}\right)_{y} \mathrm{I}_{z} \mathrm{Br}_{\mathrm{a}}+\mathrm{Fe}^{2+} \\
& \rightarrow \mathrm{FeS}_{2}+(2+3.5 x) \mathrm{HCO}_{3}^{-}+(1.5-3.5 x) \mathrm{CO}_{2} \\
& +3.5 x \mathrm{NH}_{4}^{+}+3.5 y \mathrm{H}_{3} \mathrm{PO}_{4}+z \mathrm{I}^{-}+\mathrm{aBr}^{-} .
\end{aligned}
$$

\subsection{Spatial patterns and statistical analysis of surface water quality}

Figures 9 and 10 show the solute concentrations in the four regions: Zuider Zee margin, upconing area, central Holland, and Vecht lakes. Due to insufficient surface water quality data, no results are shown for several polders in the Amsterdam city area (see Fig. 4) and the ice-pushed ridge region. The first is related to the monitoring priorities of the Waternet water board, and the latter is related to the near absence of surface water in this region.

\subsection{1 $\mathrm{Cl}$, $\mathrm{Ca}$, and $\mathrm{HCO}_{3}$}

The highest chloride levels $\left(>300 \mathrm{mg} \mathrm{L}^{-1}\right.$ ) were found in the upconing polders with brackish seepage and in a minority of the polders in the Zuider Zee margin and central Holland regions (Figs. 9 and 10). The high $\mathrm{Ca}$ and $\mathrm{HCO}_{3}$ concentrations in these polders are also related to the occurrence of brackish water. However, most of the surface water in the Zuider Zee margin and the central Holland area is fresh with relatively low $\mathrm{Cl}$ concentrations (Fig. 10). The Vecht lakes area exhibits the most fresh and least mineralised surface water.

\subsection{2 $\mathrm{SO}_{4}$ and $\mathrm{SO}_{4} / \mathrm{Cl}$}

The highest $\mathrm{SO}_{4}$ concentration levels and $\mathrm{SO}_{4} / \mathrm{Cl}$ mass ratios mostly occurred in the central Holland area, especially the western part. The elevated $\mathrm{SO}_{4}$ and $\mathrm{SO}_{4} / \mathrm{Cl}$ ratios indicate the presence of sulfate sources other than (relict) seawater in this area, probably atmospheric deposition, agriculture, and/or oxidation of pyrite exposed in the upper soils 

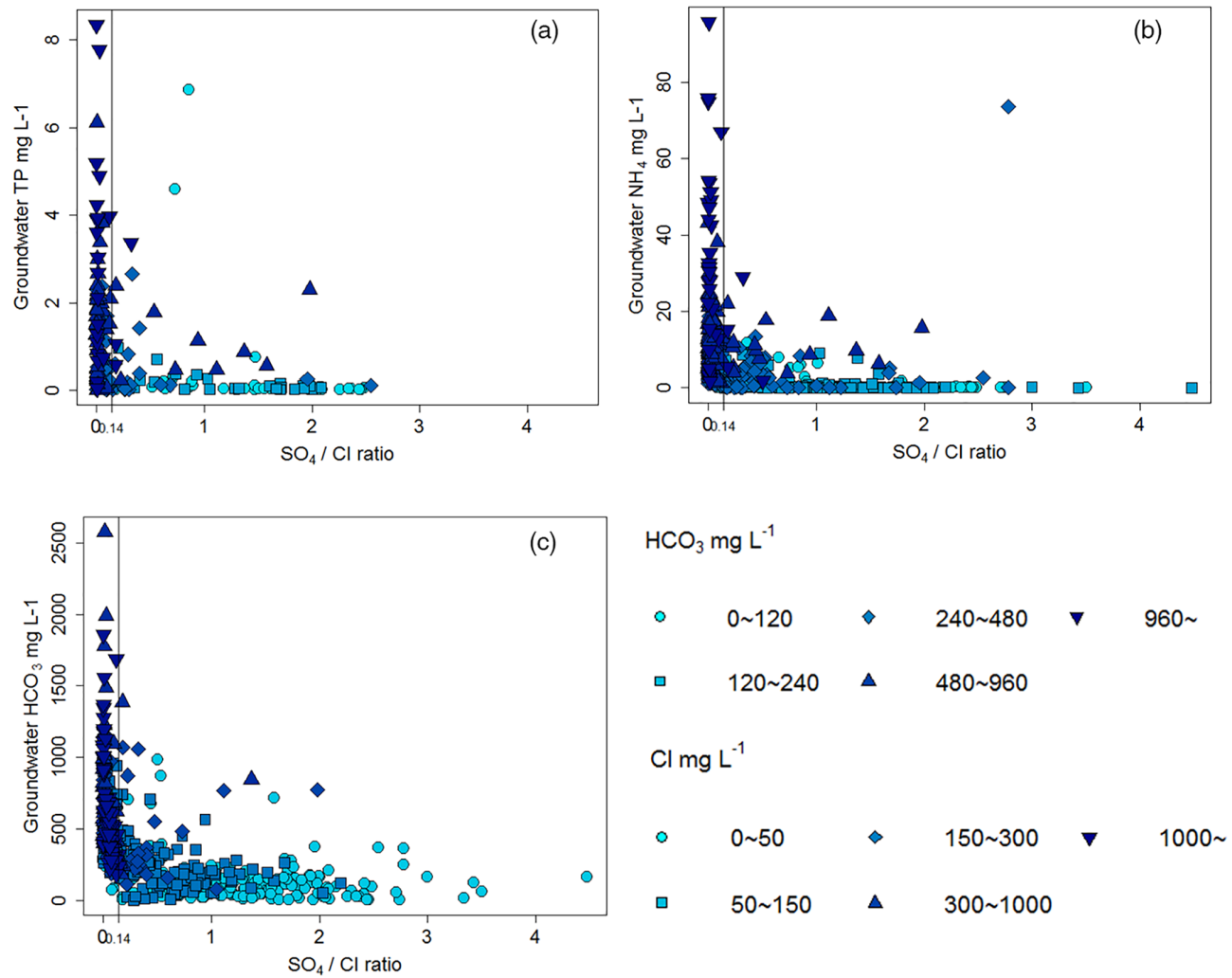

Figure 8. Groundwater nutrient ( $\mathrm{TP}$ and $\mathrm{NH}_{4}$ ) concentrations with sulfate reduction (mass ratio $\mathrm{SO}_{4} / \mathrm{Cl}$; samples with values below 0.14 are considered to be affected by sulfate reduction and above 0.14 indicates sulfate production by natural or artificial processes). The symbols in (a) and (b) are coloured by $\mathrm{HCO}_{3}$ concentration and in (c) by $\mathrm{Cl}$ concentration.

which developed in marine clay deposits and are denoted as "cat clays" (Van Wallenberg, 1975). In the Zuider Zee margin and the two upconing polders, the median $\mathrm{SO}_{4}$ levels are 64 and $62 \mathrm{mg} \mathrm{L}^{-1}$, respectively, and $\mathrm{SO}_{4} / \mathrm{Cl}$ mass ratios of the two upconing polders are below 0.14 . A generally lower $\mathrm{SO}_{4}$ with $\mathrm{SO}_{4} / \mathrm{Cl}$ ratios far exceeding the 0.14 were found in the Vecht lakes region.

\subsubsection{TN, $\mathrm{NH}_{4}, \mathrm{NO}_{3}$, and $\mathrm{TP}$}

According to Figs. 9 and 10, surface water EQSs of $\mathrm{TN}\left(2.4 \mathrm{mg} \mathrm{N} \mathrm{L}^{-1}\right)$ and $\mathrm{TP}\left(0.15 \mathrm{mg} \mathrm{PL}^{-1}\right)$ were exceeded in most polders of the study area. The outliers with even higher nutrient concentrations are mainly located in the west of the central Holland region. P25 and P75 of TP and TN in the Zuider Zee margin and in central Holland regions all significantly exceeded EQSs for surface water. In the two upconing polders, the Groot Mijdrecht polder showed higher concentrations of TP and TN than the Horstermeer polder ( 0.28 vs. $0.11 \mathrm{mg} \mathrm{PL}^{-1}$ and 5.4 vs. $1.8 \mathrm{mg} \mathrm{N} \mathrm{L}^{-1}$ ). Polders with concentrations below the EQSs were mainly situated in the Vecht lakes area where large open-water areas exist. In this region, TP slightly exceeded the EQS with a median concentration of $0.22 \mathrm{mg} \mathrm{L}^{-1}$, while the median $\mathrm{TN}$ concentration of $2.26 \mathrm{mg} \mathrm{L}^{-1}$ was just below the EQS. The concentrations of $\mathrm{NO}_{3}$ and $\mathrm{NH}_{4}$ in the Vecht lakes area were relatively low as well.

Similar to the results of groundwater, higher nutrient levels also exist in higher mineralised surface waters, which is also indicated by the correlation results (Table 1): In surface water components $\mathrm{Ca}$ and $\mathrm{HCO}_{3}$ are both correlated with $\mathrm{NH}_{4}$ (Spearman $R^{2}$ are 0.64 and 0.67), TP $\left(R^{2} 0.55,0.63\right)$, and TN $\left(R^{2} 0.56,0.47\right)$. In surface water, $\mathrm{Ca}$ and $\mathrm{HCO}_{3}$ had a significant correlation $\left(R^{2} 0.88\right)$. This indicates that groundwater is the probable source of the water and nutrients in the surface water of the polders. This groundwater impact was further supported by the correlations between the following pairs of solutes in surface water: $\mathrm{Cl}$ with $\mathrm{Ca}\left(R^{2} 0.55\right)$, $\mathrm{HCO}_{3}\left(R^{2} 0.52\right), \mathrm{SO}_{4}\left(R^{2} 0.49\right)$ and $\mathrm{NH}_{4}\left(R^{2} 0.51\right)$, as well as $\mathrm{SO}_{4}$ with TN $\left(R^{2} 0.57\right)$ and $\mathrm{NO}_{3}\left(R^{2} 0.50\right)$. A more direct indication for the groundwater impact is that $\mathrm{NH}_{4}, \mathrm{HCO}_{3}$, and $\mathrm{Ca}$ concentrations in surface water were positively related to the seepage rate. In a similar way, the groundwater impact is suggested by the negative correlations between elevation and the concentration levels of most surface water solutes (TN: $R^{2}-0.67, \mathrm{NH}_{4}: R^{2}-0.59, \mathrm{NO}_{3}: R^{2}-0.40$, $\mathrm{HCO}_{3}: R^{2}-0.48, \mathrm{SO}_{4}: R^{2}-0.47$ and $\left.\mathrm{Ca}: R^{2}-0.57\right)$.

For the soil variables (lutum, humus, and calcite), only humus showed correlations with $\mathrm{TN}, \mathrm{NH}_{4}, \mathrm{Ca}$, and $\mathrm{Cl}$ in sur- 

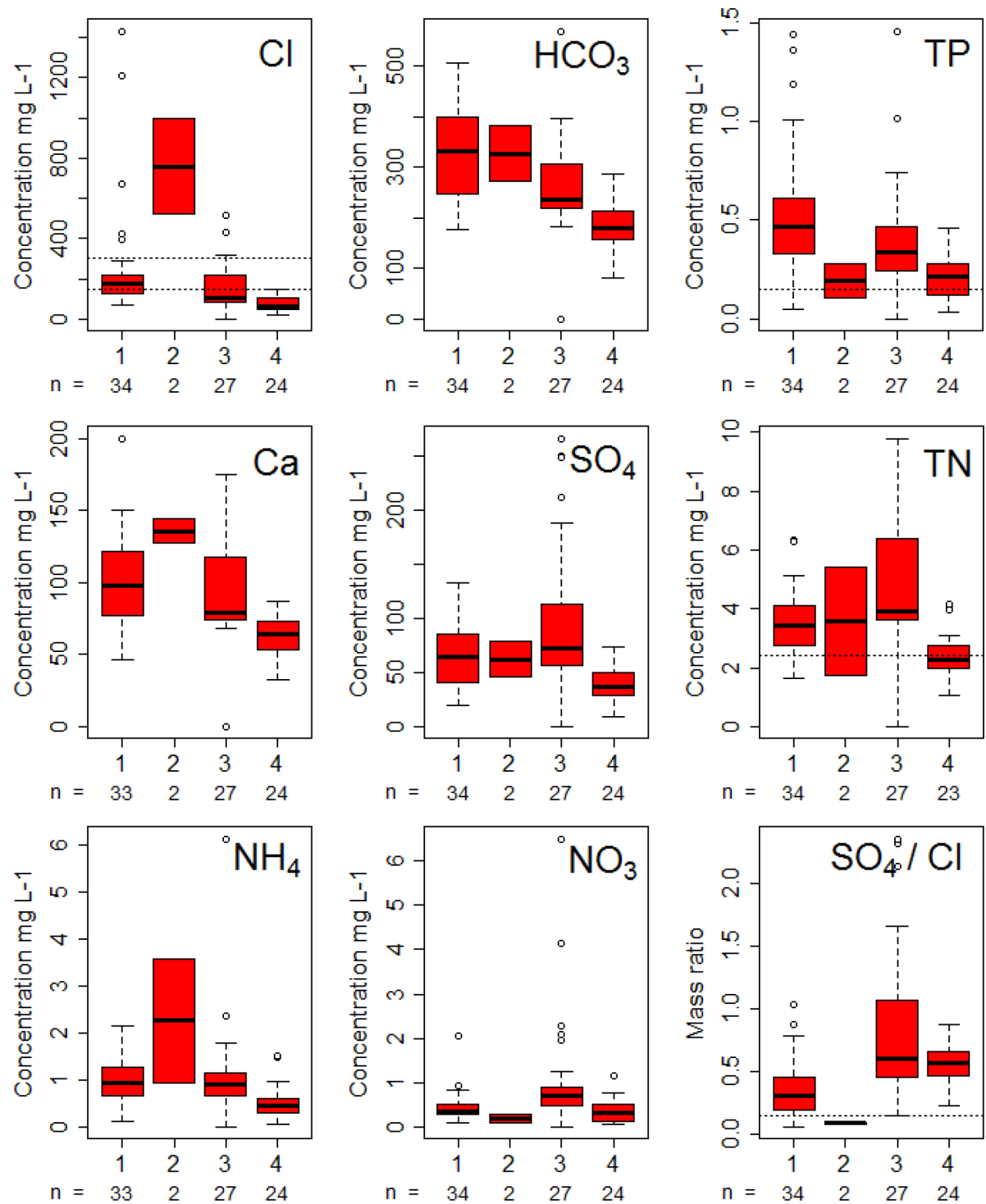

Figure 9. Spatial variation of surface water quality. (1) Zuider Zee margin, (2) upconing area, (3) central Holland, (4) Vecht lakes (5, icepushed ridge, not shown due to insufficient data). The observation number of each group is denoted by $n$. The two horizontal dashed lines for $\mathrm{Cl}$ indicate freshwater $\left(<150 \mathrm{mg} \mathrm{L}^{-1}\right)$ and brackish water $\left(>300 \mathrm{mg} \mathrm{L}^{-1}\right)$, respectively. Dashed lines in TP and TN represent EQSs for $\mathrm{TN}\left(2.4 \mathrm{mg} \mathrm{L}^{-1}\right)$ and $\mathrm{TP}\left(0.15 \mathrm{mg} \mathrm{L}^{-1}\right)$. The dashed line in the $\mathrm{SO}_{4} / \mathrm{Cl}$ plot indicates the mass ratio of 0.14 in seawater $(<0.14$ indicates sulfate reduction; $>0.14$ indicates additional sources of sulfate besides (diluted) seawater).

face water (Table 1). Paved area percentage, surface water area percentage, calcite and clay percentages, and agricultural $\mathrm{N}$ and $\mathrm{P}$ inputs did not show absolute values of correlation coefficients above 0.4 with surface water quality, but a slight negative correlation was found between the agricultural $\mathrm{N}$ input and the normalised concentrations of $\mathrm{HCO}_{3}$ in surface water (Table S2).

Surface water TN correlated more closely with $\mathrm{NH}_{4}(0.77)$ than with $\mathrm{NO}_{3}(0.57)$, which reflects that $\mathrm{NH}_{4}$ is generally the main form of $\mathrm{TN}$ in the study area. This is especially true for the Zuider Zee margin, the upconing area, and the central Holland area (Fig.9). The $\mathrm{NO}_{3}$ and $\mathrm{NH}_{4}$ contributions to TN are about equal in the Vecht lakes area. For the icepushed ridge (not shown in Fig. 9 due to insufficient data), a dominance of $\mathrm{NO}_{3}$ in surface water was expected, as was the case in groundwater of this area. However, there is only a limited amount of surface water that is draining the icepushed ridge directly.

\subsection{Groundwater and surface water quality comparison}

A common spatial pattern in surface and groundwater chemistry is that polders in the Zuider Zee margin area, the two 

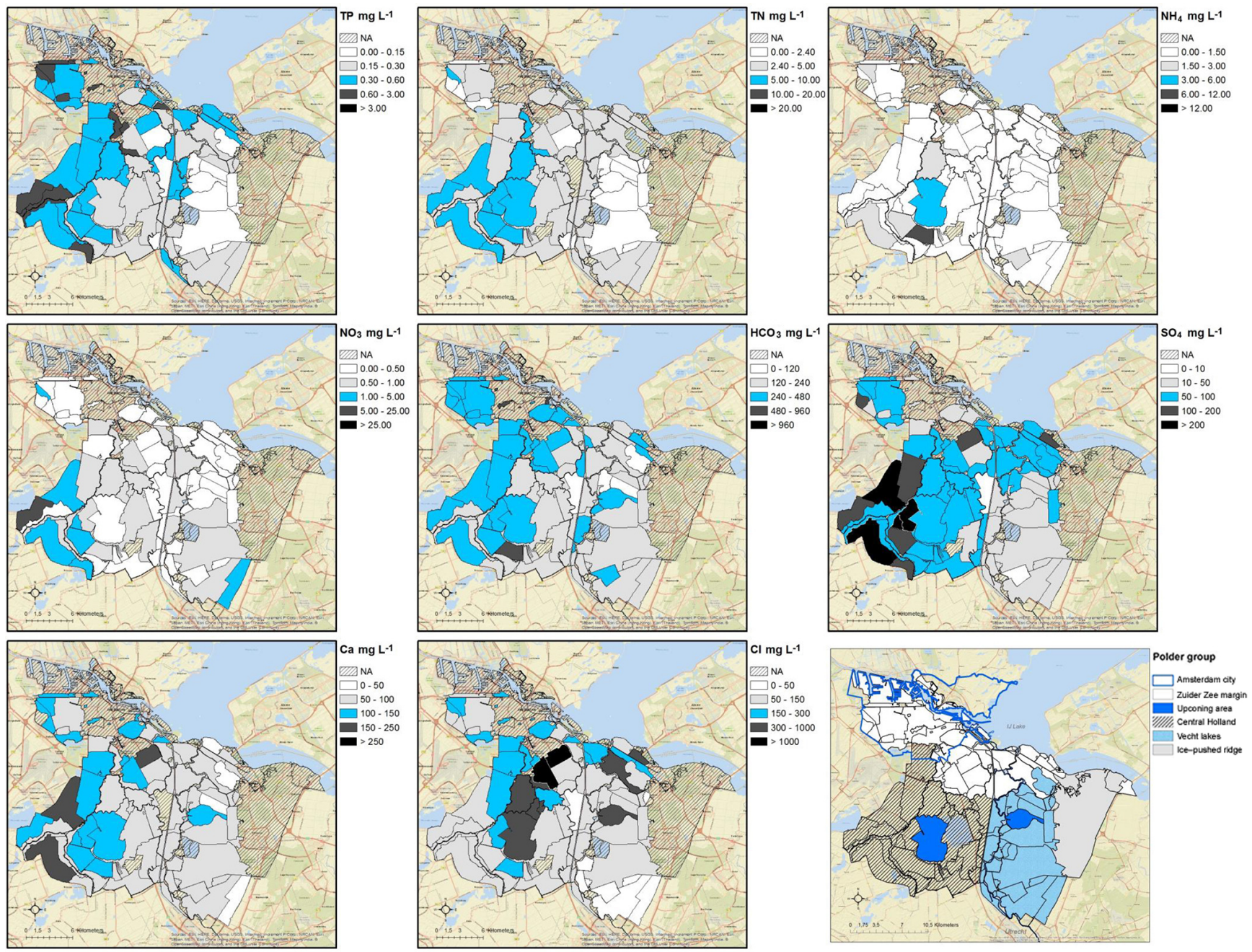

Figure 10. Discharge-normalised average concentrations $\left(\mathrm{mg} \mathrm{L}^{-1}\right)$ per polder.

upconing polders, and the central Holland area suffer from a worse water quality situation than the polders in the Vecht lakes and ice-pushed ridge areas. However, compared with the underlying groundwater quality, surface water in the whole area has much lower chloride, bicarbonate, and nutrient levels, but higher $\mathrm{SO}_{4}$ concentrations (Figs. 5 and 9). The polders generally have much higher TP and TN concentrations in groundwater than in surface water. The groundwater nutrient concentrations exceeded the surface water EQSs in $93 \%$ of the polders for TP, and in $91 \%$ for TN. Polders with groundwater nutrient levels below the EQSs were mainly found near Lake IJssel. In particular, the groundwater TN concentrations in the ice-pushed ridge severely exceeded surface water EQSs, which can be mainly attributed to the elevated $\mathrm{NO}_{3}$ concentrations. For TP in groundwater, the Zuider Zee margin and central Holland areas show more significant EQS exceedances compared to the upconing area, ice-pushed ridge, and the Vecht lakes area.
Table 2. Linear regression results of each surface water solute (Spearman).

\begin{tabular}{|c|c|c|c|c|c|c|}
\hline & $n_{1}$ & $n_{2}$ & $n_{3}$ & $R^{2}$ & $R^{2}(\mathrm{~s})$ & \\
\hline $\mathrm{TP}_{\mathrm{SW}}$ & $+\mathrm{HCO}_{3 \mathrm{GW}}$ & $+\mathrm{NH}_{4 \mathrm{GW}}$ & & 0.43 & 0.49 & (9) \\
\hline $\mathrm{TN}_{\mathrm{SW}}$ & - Elevation & $+\mathrm{HCO}_{3 \mathrm{GW}}$ & $+\mathrm{N}_{\text {input }}$ & 0.57 & 0.48 & (10) \\
\hline $\mathrm{NH}_{4} \mathrm{SW}$ & - Elevation & $+\mathrm{HCO}_{3 \mathrm{GW}}$ & + Seepage & 0.50 & 0.61 & (11) \\
\hline $\mathrm{NO}_{3 \mathrm{SW}}$ & - Elevation & $+\mathrm{N}_{\text {input }}$ & & 0.18 & 0.23 & (12) \\
\hline $\mathrm{HCO}_{3 \mathrm{SW}}$ & $+\mathrm{HCO}_{3 \mathrm{GW}}$ & + Seepage & $+\mathrm{NH}_{4 \mathrm{GW}}$ & 0.57 & 0.70 & (13) \\
\hline $\mathrm{SO}_{4 \mathrm{SW}}$ & - Elevation & $+\mathrm{SO}_{4 \mathrm{GW}}$ & & 0.25 & 0.22 & (14) \\
\hline Ca sw & $+\mathrm{HCO}_{3 \mathrm{GW}}$ & - Elevation & + Seepage & 0.65 & 0.63 & (15) \\
\hline $\mathrm{Cl}_{\mathrm{SW}}$ & $+\mathrm{Cl}_{\mathrm{GW}}$ & $+\mathrm{HCO}_{3 \mathrm{GW}}$ & $+\mathrm{P}_{\text {Humus }}$ & 0.57 & 0.51 & (16) \\
\hline \multicolumn{7}{|c|}{$\begin{array}{l}\text { * The symbols "+" and "-" denote positive relation and negative relation, respectively. The symbol } n_{1} \\
\text { means the first variable in the regression, and it is also the most significant variable. } R^{2}(\mathrm{~s}) \text { is the } R^{2} \text { with } \\
\text { only seeping polders. } \mathrm{HCO}_{3} s \mathrm{SW} \text { : surface water } \mathrm{HCO}_{3} \text { concentration }\left(\mathrm{mg} \mathrm{L}^{-1}\right) \text {. } \mathrm{HCO}_{3} \mathrm{GW} \text { : groundwater } \\
\mathrm{HCO}_{3} \text { concentration }\left(\mathrm{mg} \mathrm{L}^{-1}\right) \text {. Elevation: average polder elevation }(\text { relative to average mean sea level). } \\
\text { Seepage: seepage rate }\left(\mathrm{mm} \mathrm{yr}^{-1}\right) \text {. PHumus: percentage of humus in the soil profile sample. } \mathrm{N}_{\text {input }} \text { : manure } \\
\text { and fertiliser } \mathrm{N} \text { input }\left(\mathrm{kg} \mathrm{ha}^{-1} \mathrm{yr}^{-1}\right) \text {. }\end{array}$} \\
\hline
\end{tabular}

Table 1 shows that $\mathrm{TP}, \mathrm{NH}_{4}, \mathrm{HCO}_{3}$, and $\mathrm{Cl}$ concentrations in groundwater correlate with the same components in surface water $\left(R^{2} 0.49,0.44,0.68\right.$, and 0.69$)$. In addition, $\mathrm{HCO}_{3}$ 
in groundwater showed moderate correlations with nutrient concentrations in surface water (TP $\left(R^{2} 0.64\right), \mathrm{TN}\left(R^{2} 0.52\right)$, and $\left.\mathrm{NH}_{4}\left(R^{2} 0.51\right)\right)$. $\mathrm{HCO}_{3}$ concentrations in surface water also correlated with nutrient concentrations in surface water (TP $\left(R^{2} 0.63\right)$, TN $\left(R^{2} 0.47\right)$, and $\left.\mathrm{NH}_{4}\left(R^{2} 0.67\right)\right)$. Based on these correlations, we selected groundwater parameters and landscape characteristics to be integrated in multiple linear regression models to predict concentrations of surface water components (Table 2). For most solutes (TP, $\mathrm{NH}_{4}, \mathrm{TN}$, $\mathrm{HCO}_{3}, \mathrm{Ca}$ and $\mathrm{Cl}$ ), the $R^{2}$ of the regression models is around 0.5 , which indicates that around $40-50 \%$ of the spatial variance in surface water can be explained by specific groundwater chemistry parameters, $\mathrm{N}$ agricultural input, seepage, elevation, and humus. For $\mathrm{NO}_{3}$ and $\mathrm{SO}_{4}$, the $R^{2}$ values of the regression models (inverse with Elevation) are very low: 0.18 and 0.25 , respectively. For all other parameters, the groundwater $\mathrm{HCO}_{3}$ concentration was the best explaining variable for the surface water concentrations. The spatial variation in $\mathrm{HCO}_{3}$ Sw and Casw were relatively well explained by only $\mathrm{HCO}_{3 \mathrm{GW}}$ combined with seepage and/or elevation (Eqs. 13 and 15).

The regression models were significantly improved by including groundwater concentrations of $\mathrm{NH}_{4}, \mathrm{HCO}_{3}$, and $\mathrm{Cl}$ (Eqs. 9, 11 and 16). For $\mathrm{TN}$ and $\mathrm{NO}_{3}$, the $R^{2}$ values also improved after adding $\mathrm{N}$ agricultural input. In regression models Eqs. (10, 11, 12, 14, and 15), the elevation of the polders also explained part of the spatial variation in surface water concentrations. When only including polders with net groundwater seepage, the $R^{2}$ improved significantly for $\mathrm{TP}, \mathrm{NH}_{4}$, and $\mathrm{HCO}_{3}$.

The results above strongly suggest that the groundwater composition puts limitations on the compliance of the receiving surface water towards the EQSs defined for $\mathrm{N}$ and $\mathrm{P}$.

\subsection{Surface water solute redistribution}

Figure 11 shows that the solute loads of polders to the boezem are relatively high in the Zuider Zee margin, the upconing polders, and the central Holland regions. The Vecht lakes area has large open-water areas and showed the lowest loads to the boezem system. A clear similarity between the spatial patterns of the solute loads and the average seepage rate patterns was observed in Figs. 3 and 11. In general, polders with high seepage rates also discharge relatively high loads to the boezem system. Some examples of polders with relatively high seepage rates are polder no. 119 (Bethunepolder, $13 \mathrm{~mm} \mathrm{~d}^{-1}$ ), no. 79 (Horstermeer, $\left.8.7 \mathrm{~mm} \mathrm{~d}^{-1}\right)$, no. 50 (Polder De Toekomst, $2.4 \mathrm{~mm} \mathrm{~d}^{-1}$ ), no. 131 (Hilversumse Meent, $2.4 \mathrm{~mm} \mathrm{~d}^{-1}$ ), no. 98 (Polder Wilnis-Veldzijde, $3.7 \mathrm{~mm} \mathrm{~d}^{-1}$ ), no. 80 (Polder Groot Mijdrecht en Polder de Eerste Bedijking (oost), $5.0 \mathrm{~mm} \mathrm{~d}^{-1}$ ), no. 74 (Polder de Nieuwe Bullewijk en Holendrechter- en Bullewijker Polder noord, $1.8 \mathrm{~mm} \mathrm{~d}^{-1}$ ), and no. 75 (Bijlmer, $2.0 \mathrm{~mm} \mathrm{~d}^{-1}$ ). The highest loads are discharged from the two upconing polders: Groot Mijdrecht (no. 80) and Horstermeer (no. 79).

The influence of the redistribution of the large water volumes and loads from deep polders was also observed in Figs. 3 and 11. Polders that receive inlet water from Groot Mijdrecht and Horstermeer (see Sect. 2.1.1, Fig. 3) showed relatively high solute loads, independent of their own seepage or infiltration fluxes. This especially holds for polders downstream of Groot Mijdrecht and Horstermeer, like polder no. 73 (Holendrechter- en Bullewijker Polder (zuid en west), -0.05), no. 74 (Polder de Nieuwe Bullewijk en Holendrechter- en Bullewijker Polder noord, $1.8 \mathrm{~mm} \mathrm{~d}^{-1}$ ), no. 104 (Noorderpolder of Botshol (zuid en west), $-1.4 \mathrm{~mm} \mathrm{~d}^{-1}$ ), no. 105 (Noorderpolder of Botshol (Nellestein), $-0.7 \mathrm{~mm} \mathrm{~d}^{-1}$ ), no. 106 (Polder de Rondehoep, $-1.1 \mathrm{~mm} \mathrm{~d}^{-1}$ ), and polder no. 107 (Polder Waardassacker en Holendrecht, $-0.15 \mathrm{~mm} \mathrm{~d}^{-1}$ ).

The impact of this redistributed water on polder water chemistry is demonstrated by a simple water and solute mass balance calculation for the receiving Botshol polder (see Sect. 2.2.4). Figure 12 gives the chloride concentration results of both the "evaporation" and the "infiltration/outlet" models. Figure 12 shows that a very simple model can easily explain the peak $\mathrm{Cl}$ concentrations in the Botshol polder to be the result of the inlet of water from the boezem and Groot Mijdrecht. The "evaporation" model performs better in 2006 and 2008 and the "infiltration/outlet" model in 2011 and 2012. Most of the time, the measured concentrations are between the calculated concentrations from both models. This aligns with the understanding that water leaves Botshol via a combination of evapotranspiration and other outflow routes, such as infiltration, leakage, and outlets.

\section{Discussion}

This study aimed at identifying the impact of groundwater on surface water quality in the polder catchments of the greater Amsterdam city area. According to the statistical analysis of data over five regions in the study area, a clear influence was identified. Solute concentrations in groundwater and surface water correlated well, although groundwater solute concentrations were generally much higher than normalised concentrations in surface water. The latter seems logical given the dilution of surface water by the precipitation surplus on an annual basis, with the annually discharged surface water being a mixture of seeping groundwater and precipitation. Moreover, similar spatial patterns in solute concentrations were found in groundwater and surface water. The findings on the dominance of groundwater inputs is also supported by the poor correlation with agricultural nutrients inputs, which are usually assumed to be a large source of $\mathrm{N}$ and $\mathrm{P}$ in surface water. Polders that are influenced by groundwater seepage or by redistributed seepage water from nearby deep polders are at risk of non-compliance, as groundwater concentrations ex- 


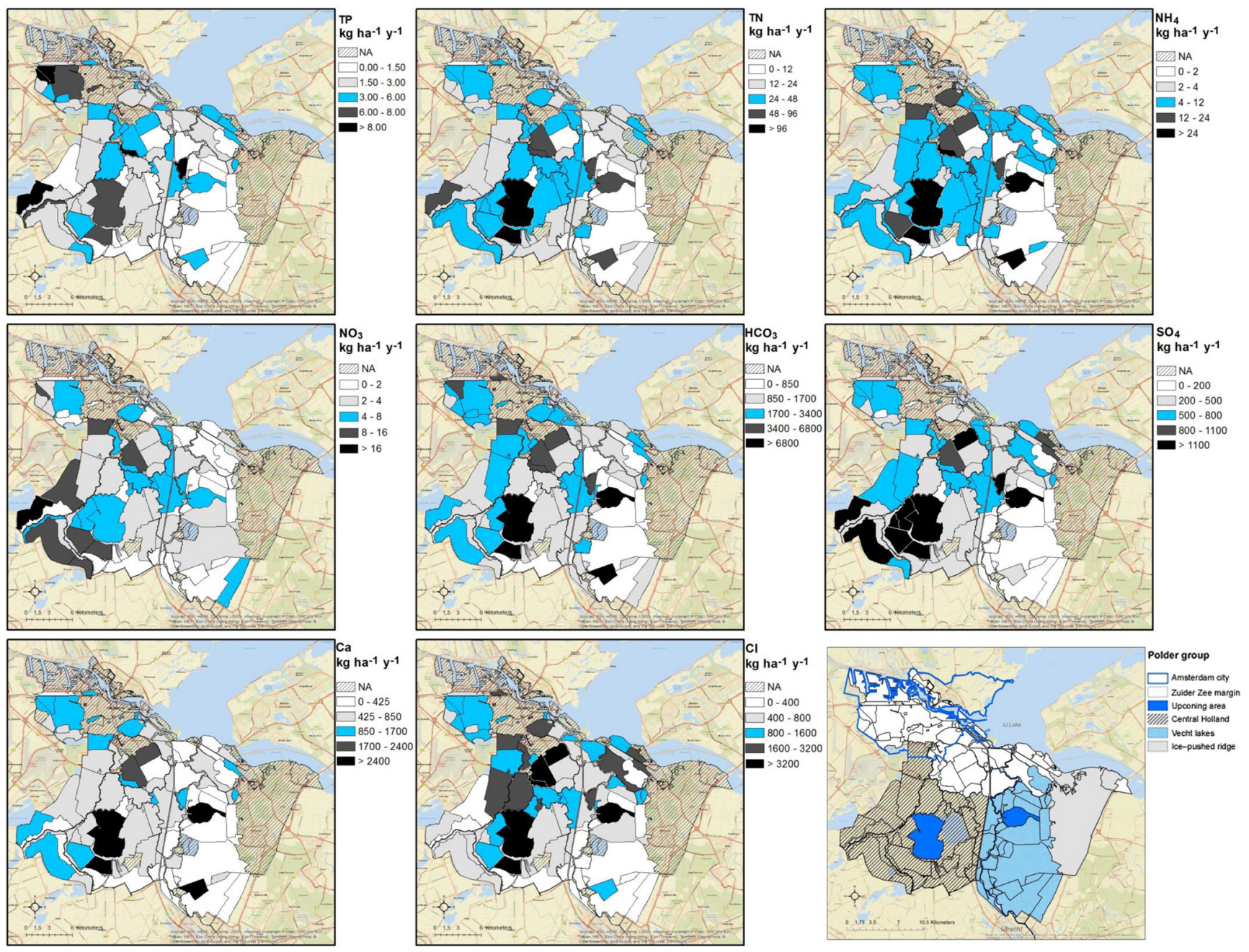

Figure 11. Surface water solute loads (average of 2010 to 2013) distribution maps $\left(\mathrm{kg} \mathrm{ha}^{-1} \mathrm{yr}^{-1}\right)$.

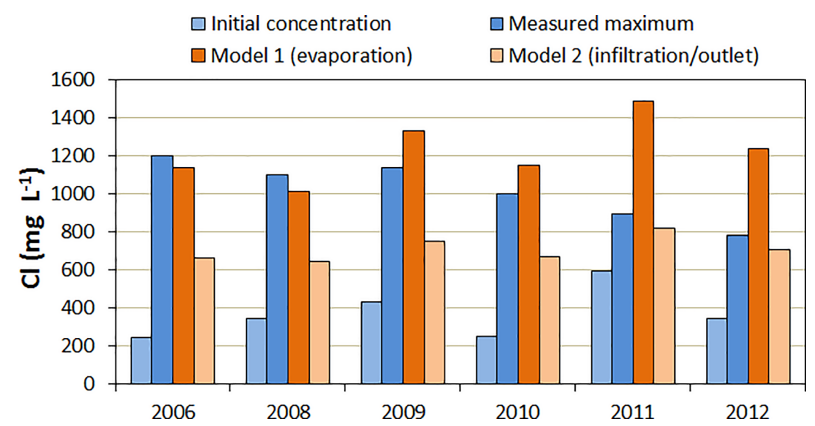

Figure 12. Summary of the water and chloride balance for the Botshol polder; the graph shows (1) the initial $\mathrm{Cl}$ before the water inlet season (light blue), (2) the resulting $\mathrm{Cl}$ peak in Botshol after some months of inlet (dark blue), and (3) the results of the two models (model 1 is dark orange, model 2 is light orange). ceeded the TN and TP EQSs for surface water in more than $90 \%$ of the polders. Consequently, the groundwater nutrients input hinders the achievement of water quality targets in the surface water in those lowland landscapes.

\subsection{Key hydro-chemical processes}

In general, the groundwater chemistry corresponds with the geological history of the study area. In the peatland polder catchments within the Dutch delta system of marine, perimarine, and fluvial unconsolidated deposits, abundant organic matter is present in the subsurface (e.g. Hijma, 2009). The presence of reactive organic matter in the shallow subsurface depletes the infiltrating groundwater from oxygen and nitrate, leading to an overall low redox potential in groundwater, which enables the further decomposition of organic matter downstream.

Our data strongly suggest that sulfate reduction, sometimes in combination with methanogenesis, is the main process releasing nutrients $(\mathrm{N}, \mathrm{P})$ and $\mathrm{HCO}_{3}$ from the organic- 
Table 3. Main hydrogeochemical reactions in the study area.

\begin{tabular}{|c|c|c|}
\hline Process & Reactions & No. \\
\hline Organic matter decomposition & $\begin{array}{l}\mathrm{CH}_{2} \mathrm{O} \mathrm{N}_{x} \mathrm{P}_{y} \rightarrow x \mathrm{~N}+y \mathrm{P}+\mathrm{HCO}_{3}^{-}+\text {other components } \\
\mathrm{CH}_{2} \mathrm{O} \mathrm{N}_{x} \mathrm{P}_{y}+\mathrm{O}_{2} \rightarrow \mathrm{CO}_{2}+\mathrm{H}_{2} \mathrm{O}+x \mathrm{~N}+y \mathrm{P} \\
5 \mathrm{CH}_{2} \mathrm{O} \mathrm{N}_{x} \mathrm{P}_{y}+4 \mathrm{NO}_{3}^{-} \rightarrow 2 \mathrm{~N}_{2}+\mathrm{CO}_{2}+4 \mathrm{HCO}_{3}^{-}+3 \mathrm{H}_{2} \mathrm{O}+5 x \mathrm{~N}+5 y \mathrm{P} \\
2 \mathrm{CH}_{2} \mathrm{O} \mathrm{N}_{x} \mathrm{P}_{y}+\mathrm{SO}_{4}^{2-} \rightarrow \mathrm{H}_{2} \mathrm{~S}+2 \mathrm{HCO}_{3}^{-}+2 x \mathrm{~N}+2 y \mathrm{P}\end{array}$ & $\begin{array}{l}\text { R2 } \\
\text { R3 } \\
\text { R4 } \\
\text { R5 }\end{array}$ \\
\hline Pyrite oxidation & $\begin{array}{l}2 \mathrm{CH}_{2} \mathrm{O} \mathrm{N}_{x} \mathrm{P}_{y} \rightarrow \mathrm{CH}_{4}+\mathrm{CO}_{2}+2 x \mathrm{~N}+2 y \mathrm{P} \\
2 \mathrm{FeS}_{2}+7 \mathrm{O}_{2}+2 \mathrm{H}_{2} \mathrm{O} \rightarrow 2 \mathrm{Fe}^{2+}+4 \mathrm{SO}_{4}^{2-}+4 \mathrm{H}^{+} \\
5 \mathrm{FeS}_{2}+14 \mathrm{NO}_{3}^{-}+4 \mathrm{H}^{+} \rightarrow 5 \mathrm{Fe}^{2+}+10 \mathrm{SO}_{4}^{2-}+7 \mathrm{~N}_{2}+2 \mathrm{H}_{2} \mathrm{O}\end{array}$ & $\begin{array}{l}\text { R6 } \\
\text { R7 } \\
\text { R8 }\end{array}$ \\
\hline Calcite dissolution & $\begin{array}{l}\text { Closed system } \mathrm{CaCO}_{3}+\mathrm{H}_{2} \mathrm{O} \leftrightarrow \mathrm{Ca}^{2+}+\mathrm{HCO}_{3}^{-}+\mathrm{OH}^{-} \\
\text {Open system } \mathrm{CaCO}_{3}+\mathrm{CO}_{2}+\mathrm{H}_{2} \mathrm{O} \leftrightarrow \mathrm{Ca}^{2+}+2 \mathrm{HCO}_{3}^{-}\end{array}$ & $\begin{array}{r}\mathrm{R} 9 \\
\mathrm{R} 10\end{array}$ \\
\hline
\end{tabular}

rich subsurface in the study area, especially in both the fresh and brackish groundwater of the Zuider Zee margin, the upconing polders, and the central Holland that are characterized by low $\mathrm{SO}_{4} / \mathrm{Cl}$ ratios (Table 1, Fig. 8). The Holocene marine transgression undoubtedly influenced the chemistry of groundwater by salinising processes that also increased sulfate availability derived from diluted seawater. Refreshing of the aquifers by infiltration of freshwater from rivers and rain in more elevated polders and lakes further influenced part of the groundwater. We examined the amount of freshening and salinisation using the exchange $\mathrm{Na}\left(\mathrm{Na}_{\mathrm{ex}}\right)$ and investigated how this process may have influenced the release of $\mathrm{P}$, as was suggested by Griffioen et al. (1994). Figure S2 in the Supplement shows that high $\mathrm{P}$ (and $\mathrm{HCO}_{3}$, not shown) does occur in both refreshing water $\left(\mathrm{Na}_{\mathrm{ex}}>1\right)$ and in salinising water $\left(\mathrm{Na}_{\mathrm{ex}}<-1\right)$, but mainly when the $\mathrm{SO}_{4} / \mathrm{Cl}$ ratio is below 0.14 . Therefore, we infer that sulfate-reduction-induced organic matter decomposition is the prime process in releasing $\mathrm{P}$ and is more discriminating of high $\mathrm{P}$ than cation exchange processes. There is a high probability for sulfate-reductiondominated polder catchments to have very high $\mathrm{HCO}_{3}$ concentration in groundwater according to Reaction (R1). In our study area, high $\mathrm{HCO}_{3}$ concentration levels in both groundwater and surface water were mainly present in areas with marine sediments that contain shell fragments and organic matter. The base level groundwater alkalinity from the dissolution of shell fragments and carbonate minerals is further increased by the organic matter decomposition in the subsurface. This observation confirms the earlier findings of Griffioen et al. (2013) who highlighted the relation between the nutrient concentrations and $\mathrm{pCO}_{2}$ in these marine sediments. The main chemical reactions involved are listed in Table 3.

The seepage of the alkalised groundwater increases the alkalinity of the surface water, which is indicated by the high correlation between groundwater and surface water $\mathrm{HCO}_{3}$, and with $\mathrm{Ca}$ in surface water (Table 1). Subsurface organic matter mineralisation by processes like sulfate reduction and methanogenesis (Chapelle et al., 1987; Griffioen et al., 2013) (Table 3, Reactions R5 and R6), is a probable ma- jor reason for enhanced surface water $\mathrm{HCO}_{3}$ in polders with brackish groundwater, like the polders in the Zuider Zee margin and the upconing polders.

In the urban area of Amsterdam, sand suppletion, which varies greatly in thickness and chemical composition, is another source of alkalinity. Some of the sands contain shell fragments because of their marine origin. However, little is known about the distribution of these calcite-rich sands. The poorly registered spatial distribution and sources of the supplied calcite-rich sands might complicate the assessment of their impact on urban polder water quality.

Sulfate concentrations are higher in the receiving surface water than in the groundwater. We ascribe the sulfate surpluses (Fig. 7) to additional sources affecting the surface water, including atmospheric deposition, agricultural inputs, sewer leakage (Ellis, et al., 2005), storm runoff, and/or the oxidation of pyrite $\left(\mathrm{FeS}_{2}\right)$. Pyrite is ubiquitous in this area (Griffioen et al., 2013) and oxidises in the topsoil, where either $\mathrm{O}_{2}$ or $\mathrm{NO}_{3}$ can act as electron acceptor (Van Wallenburg, 1975). We suggest that sulfate concentrations are especially high in polders where shallow groundwater flow is enhanced by the presence of tile drains in clay-rich polders that needed this drainage system to prevent water tables rising into the root zone in wet periods. Tile drain flow can bring the released $\mathrm{SO}_{4}$ to the surface water. For urban polders with high $\mathrm{SO}_{4}$ concentrations, like the Zuider Zee margin region polders, sewer system leakage may be an additional source of $\mathrm{SO}_{4}$. Aging and faulty connections of pipes may result in a leakage of water with high $\mathrm{SO}_{4}$ and nutrient concentrations.

\subsection{Groundwater contribution to surface water composition}

The groundwater in the upper $50 \mathrm{~m}$ of the subsurface of the study area is an important source of nutrients in the study area's surface waters (Delsman, 2015). Brackish groundwater, especially, seeps up into the polders of the Zuider Zee margin region and into the upconing area. The seepage of paleo-marine, brackish groundwater is driven by the low sur- 
face water levels after the lake reclamation and the drainage via pumping stations. De Louw et al. (2010) reported that this groundwater seepage predominantly takes place via concentrated boiling through the clay and peat cover layer.

The excess water in the upconing area is re-used as inlet water for several downstream polder catchments, which extends the impact of the brackish, alkaline, and nutrient-rich groundwater to a larger scale. The water redistribution disturbs the "natural" surface water quality patterns and local groundwater impact in the receiving polders, such as the Botshol polder. The redistributed water largely infiltrates and returns with variable travel times via the groundwater system, back towards the deep upconing polders.

Groundwater seepage in our study area leads to eutrophication, and redistributing the discharge from some deep polders further spreads the nutrients into the whole water system. Similar patterns are expected to exist in other lowland areas, which are highly manipulated by human activities. Typical delta areas where subsurface processes are expected to release nutrients from reactive organic matter and peat in the subsurface are the Mekong delta (Minderhoud et al., 2017), the Mississippi delta (Törnqvist et al., 2008), and the Sacramento-San Joaquin delta (Drexler et al., 2009). In many of these areas the water management shows resemblance to the Dutch situation. However, the large amount of groundwater quality and surface water quality data that were available in our study area is unique. Still, signals of groundwater influence on nutrient concentrations were reported from eastern England (M. E. Stuart, British Geological Survey, personal communication, 2016) and from the lowland parts of Denmark (Kronvang et al., 2013).

\subsection{Other sources of nutrients}

Besides the contribution from nutrient-rich groundwater seepage, this study indicated that there are other possible sources of nutrients in the study area. In agricultural lands, a portion of the applied nutrients is typically lost to the surface water via drainage and runoff. The high groundwater $\mathrm{NO}_{3}$ concentrations in the ice-pushed ridge are caused by the infiltration of agricultural water (Schot and van der Wal, 1992). The high nitrate loads and concentrations in surface water and groundwater of the polders in the southeast (e.g. no. 122 (Muyeveld), no. 140 ('t Gooi)) originate from agricultural activities in surrounding polders.

In the urban polders within the Amsterdam city that have no significant seepage (average seepage $\leq 0$ ), TP and TN EQSs are frequently exceeded because of intensive human activities such as application of fertiliser, feeding ducks and fish, and point emissions like sewer overflow leakage from the sewer system (M. Ouboter, Waternet, personal communication, 2016).

In the study area, the most intensively urbanised polders are mainly infiltrating and are more affected by inlet water containing high $\mathrm{Cl}$ and $\mathrm{HCO}_{3}$ concentrations than by ground- water. For deep urban polders, the situation is different. In these polders, the influences of typical urbanisation-related water quality issues are masked by the large impact of brackish, nutrient-rich groundwater exfiltration. Although land use was incorporated in variables like paved area percentage and $\mathrm{N}$ and $\mathrm{P}$ inputs, (as well as agricultural land percentage, shown in the Supplement), land use seems not be the dominant landscape characteristic that governs the spatial patterns in polder surface water quality. Urban water quality is determined by multiple factors, as was also concluded by several other studies (Göbel et al., 2007; Vermonden et al., 2009). However, a better measurement method or classification of paved area percentage may improve the explanatory power of this variable (Brabec et al., 2002).

The Vecht lakes polders with high surface water area percentages, representing lakes that are mainly used for recreation purposes, showed relatively low solute concentrations and loads in surface water (Figs. 10 and 11). In our study area, many lakes and polders with large surface water areas show large infiltration rates due to their elevation relative to other polders (Vermaat et al., 2010). Moreover, some of these lakes are replenished by inlet water that has passed a phosphate purification unit. In addition, the large open-water area retains nutrient transport due to long residence times and ample opportunities for chemical and biological transformation processes like denitrification, adsorption, and plant uptake.

\subsection{Uncertainties}

Due to the disturbance of urban constructions, combined with redistribution of water through artificial drainage corridors, water flow in lowland urban areas is more complex than in rural or non-low-lying and freely draining catchments. Natural patterns of water chemistry might be significantly disturbed and hydrochemical processes are masked. The understanding of urban water quality patterns might improve if the monitoring program would be extended with tracers that are typical for specific sources, such as sewage leakage or urban runoff. Most solutes that are currently measured can originate from various anthropogenic and natural sources.

In the statistical analysis, for each pair of variables, only polders with complete data were taken into account, which could result in a loss of information. Seepage data were simulated by a group of models of which the results may deviate from the hard to measure actual seepage. We used averages of groundwater concentrations and soil properties, which caused a loss of information on the spatial variation within the polders. The interpolation of groundwater quality data also added uncertainty: for example hidden correlations for groundwater parameters. The calculation of the agricultural $\mathrm{N}$ and $\mathrm{P}$ inputs may also differ from the actual inputs due to errors in the nutrient bookkeeping and model uncertainties. In addition, differences in sampling methods and analytical procedures between groundwater and surface water quality monitoring programs may add uncertainties. These 
uncertainties may all have influenced the data characteristics apart from the uncertainties in the concentration measurements caused by the sampling, transport, and analytical procedures.

\subsection{Perspectives}

In future studies, urban lowland catchments with and without seepage could be studied separately, and more detailed land use or paved area categories could be included. The drainage and/or leakage from sewage systems and the drainage via tube drains should be taken into consideration. Drainage systems can provide a shortcut for solute transport towards surface water (Rozemeijer and Broers, 2007), leading to higher solute concentrations in surface water. High groundwater levels may induce groundwater discharge via the sewage or drainage systems (Ellis et al., 2005). In addition, studying the temporal variation of surface water quality will give more insights into how the groundwater impact on surface water quality functions, as well as on solute transport and pathways in urban hydrological systems. A detailed monitoring network in several urban polder catchments, which is anticipated as further work, could yield a more complete insight into water and contaminant flow routes and their effects on surface water solute concentrations and loads.

With respect to the water management scenarios, as our study showed that the groundwater nutrient loading towards surface water dominates, reducing the amounts of agricultural nutrient inputs might not contribute enough in improving the water quality. This certainly holds for urban areas where agricultural inputs are absent (see Fig. S3). Given the large loads of $\mathrm{N}$ and $\mathrm{P}$ that originate from one large polder with upconing brackish groundwater - the Groot Mijdrecht polder - one of the solutions proposed in the Netherlands was to turn this area back into a freshwater lake. By doing so, the seepage of nutrient-rich groundwater would stop as the higher water levels would lead to neutral or even infiltrating conditions. However, this proposal led to a lot of protest among the municipalities and farming communities in the polder and was not considered feasible given the economic values that were involved. This example shows that the reclamation of swamps and lakes for urbanisation or agriculture can lead to increased nutrient loads to surface waters in the surroundings, which are hard to mitigate. This scenario has wider implications for water management in other urbanising lowland areas around the world.

\section{Conclusion}

In this paper, a clear groundwater impact on surface water quality was identified for the greater Amsterdam area. It was concluded that this groundwater seepage significantly impacts surface water quality in the polder catchments by introducing brackish, alkaline, and nutrient-rich water. In general, nutrient concentrations in groundwater were much higher than in surface water and often exceeded surface water environmental quality standards (in $93 \%$ of the polders with available data for TP and in $91 \%$ for TN), which indicates that groundwater is a large potential source of nutrients in surface water. Our results strongly suggest that organic matter mineralisation is a major source of nutrients in lowland deltas where water levels are lowered to enable urbanisation and agricultural land use. High correlations $\left(R^{2}\right.$ up to 0.88 ) between solutes in groundwater and surface water confirmed the effects of surface water-groundwater interaction on surface water quality. In seepage polders in particular, groundwater is a major source of $\mathrm{Cl}, \mathrm{HCO}_{3}, \mathrm{Ca}$, and the nutrients $\mathrm{N}$ and $\mathrm{P}$, leading to general exceedances of EQSs for $\mathrm{N}$ and $\mathrm{P}$ in surface waters. The discharge and redistribution of nutrient-rich water from reclaimed lakes and swamps enhances eutrophication in downstream water resources and is hard to mitigate. Surface water quality in the Amsterdam urban area is also influenced by groundwater seepage, but other anthropogenic sources, such as leaking and overflowing sewers, might amplify the eutrophication problems.

Data availability. The data statistically processed in this paper are available in the Supplement.

\section{The Supplement related to this article is available online at https://doi.org/10.5194/hess-22-487-2018-supplement.}

Competing interests. The authors declare that they have no conflict of interest.

Acknowledgements. This work was funded through a CSC scholarship (no. 201309110088) and supported by the Strategic Research Funding of TNO and Deltares. We would like to thank the Waternet organization for making available their regional data on surface water quality, and we appreciate the contributions by Jos Beemster, Jan Willem Voort, and Jasper Stroom.

Edited by: Nandita Basu

Reviewed by: two anonymous referees

\section{References}

Appelo, C. A. J. and Postma, D.: Geochemistry, groundwater and pollution, Second Edition, A.A. Balkema Publishers, Leiden, the Netherlands, 2005.

Brabec, E., Schulte, S., and Richards, P. L.: Impervious Surfaces and Water Quality: A Review of Current Literature and Its Implications for Watershed Planning, J. Plan. Lit., 16, 499-513, 2002. 
Chapelle, F. H., Zelibor, J. L., Grimes, D. J., and Knobel, L. L.: Bacteria in deep coastal plain sediments of Maryland: a possible source of $\mathrm{CO}_{2}$ to groundwater, Water Resour. Res., 23, 16251632, 1987.

De Louw, P. G. B., Oude Essink, G. H. P., Stuyfzand, P. J., and van der Zee, S. E. A. T. M.: Upward groundwater flow in boils as the dominant mechanism of salinization in deep polders, the Netherlands, J. Hydrol., 394, 494-506, 2010.

Delsman, J. R.: Saline Groundwater - Surface Water Interaction in Coastal Lowlands, PhD thesis, VU University Amsterdam, Amsterdam, the Netherlands, 2015.

Delsman, J. R., Hu-a-ng, K. R. M., Vos, P. C., de Louw, P. G. B., Oude Essink, G. H. P., Stuyfzand, P. J., and Bierkens, M. F. P.: Paleo-modeling of coastal saltwater intrusion during the Holocene: an application to the Netherlands, Hydrol. Earth Syst. Sci., 18, 3891-3905, https://doi.org/10.5194/hess-18-3891-2014, 2014.

Dinoloket: Groundwater quality database, available at: https://www. dinoloket.nl/, last access: 14 October 2016.

Drexler, J. Z., De Fontaine, C. S., and Deverel, S. J.: The legacy of wetland drainage on the remaining peat in the Sacramento San Joaquin Delta, California, USA, Wetlands, 29, 372-386, 2009.

Ellis, J. B., Marsalek, J., and Chocat, B.: Encyclopedia of Hydrological Sciences, Urban Water Quality, 1st edition, M. G. Anderson, John Wiley \& Sons, Ltd, United States, 8, 97, 2005.

EU: Commission Staff Working Document; the EU Environmental Implementation Review. Country Report - the Netherlands, the EU Environmental Implementation Review: Common Challenges and how to combine efforts to deliver better results, $\operatorname{COM(2017)} 63$ final, available at: http://ec.europa. eu/environment/eir/pdf/report_nl_en.pdf, last access: 24 November 2017.

Garrett, C. G., Vulava, V. M., Callahan, T. J., and Jones, M. L.: Groundwater-surface water interactions in a lowland watershed: source contribution to stream flow, Hydrol. Process., 26, 31953206, 2012.

Göbel, P., Dierkes, C., and Coldewey, W. G.: Storm water runoff concentration matrix for urban areas, J. Contam. Hydrol., 91, 2642, 2007.

Griffioen, J.: Uptake of phosphate by iron hydroxides during seepage in relation to development of groundwater composition in coastal areas, Environ. Sci. Technol., 28, 675-681, 1994.

Griffioen, J., Vermooten, S., and Janssen, G.: Geochemical and palaeohydrological controls on the composition of shallow groundwater in the Netherlands, Appl. Geochem., 39, 129-149, 2013.

Heinis, F. and Evers, C. H. M.: Toelichting op ecologische doelen voor nutrienten in oppervlaktewateren. STOWA-report, Utrecht, the Netherlands, 2007 (in Dutch).

Helsel, D. R. and Hirsch, R. M.: Statistical Methods in Water Resources, Techniques of Water Resources Investigations, 2nd edition, U. S. Geological Survery, USA, Book 4, chapter A3, 2002.

Hellmann, F. and Vermaat, J. E.: Impact of climate change on water management in Dutch peat polders, Ecol. Model., 240, 74-83, 2012.

Hijma, M. P.: From river valley to estuary: the early-mid Holocence transgression of the Rhine-Meuse valley, $\mathrm{PhD}$ thesis, Utrecht University, Utrecht, the Netherlands, 2009.
Holman, I. P., Whelan, M. J., Howden, N. J. K., Bellamy, P. H., Willby, N. J., Rivas-Casado, M., and McConvey, P.: Phosphorus in groundwater - an overlooked contributor to eutrophication, Hydrol. Process., 22, 5121-5127, 2008.

Huisman, P., Cramer, W., van Ee, G., Hooghart, J. C., Salz, H., and Zuidema, F. C.: Water in the Netherlands. Netherlands Hydrological Society, Rotterdam, the Netherlands, 1998.

Kronvang, B., Køgestrand, J., Windolf, J., Ovesen, N., and Troldborg, L.: Background phosphorus concentrations in Danish groundwater and surface water bodies, EGU General Assembly 2013, 7-12 April, 2013, Vienna, Austria, id. EGU2013-2249, 2013.

Meinikmann, K., Hupfer, M., and Lewandowski, J.: Phosphorus in groundwater discharge - A potential source for lake eutrophication, J. Hydrol., 524, 214-226, 2015.

Minderhoud, P. S. J., Erkens, G., Pham, V. H., Bui, V. T., Erban, L., Kooi, H., and Stouthamer, E.: Impacts of 25 years of groundwater extraction on subsidence in the Mekong delta, Vietnam, Environ. Res. Lett., 12, 1-13, 2017.

Morris, A. W. and Riley, J. P.: The bromide/chlorinity and sulphate/chlorinity ratio in sea water, Deep Sea Research and Oceanographic Abstracts, 13, 699-705, https://doi.org/10.1016/0011-7471(66)90601-2, 1966.

Mourad, D. S. J. and van der Perk, M.: Spatio-temporal patterns of nutrient concentrations and export in a north-eastern European lowland catchment, Hydrol. Process, 23, 1821-1833, 2009.

Neumann, B., Vafeidis, A. T., Zimmermann, J., and Nicholls, R. J.: Future Coastal Population Growth and Exposure to Sea-Level Rise and Coastal Flooding - A Global Assessment, Plos One, 10, e0118571, https://doi.org/10.1371/journal.pone.0118571, 2015.

Oude Essink., G. H. P., Houtman, H., and Goes, B. J. M.: Chloride concentration at the bottom of the Holocene aquitard in the Netherlands, Rep. NITG 05-056-A, 17 pp., TNO, Utrecht, Netherlands, 2005 (in Dutch).

Oude Essink, G. H. P., Van Baaren, E. S., and De Louw, P. G. B.: Effects of climate change on coastal groundwater systems: a modeling study in the Netherlands, Water Resour. Res., 46, 1-16, 2010.

Rozemeijer, J. C. and Broers, H. P.: The groundwater contribution to surface water contamination in a region with intensive agricultural land use (Noord-Brabant, the Netherlands), Environ. Pollut., 148, 695-706, 2007.

Rozemeijer, J. C., Van der Velde, Y., Van Geer, F. C., Bierkens, M. F. P., and Broers, H. P.: Direct measurements of the tile drain and groundwater flow route contributions to surface water contamination: From field-scale concentration patterns in groundwater to catchment-scale surface water quality, Environ. Pollut., 158, 3571-3579, 2010.

Rozemeijer, J. C., Van der Velde, Y., Van Geer, F., de Rooij, G. H., Torfs, P. J. J. F., and Broers, H. P.: Improving load estimates of $\mathrm{N}$ and $\mathrm{P}$ in surface waters by characterizing the concentration response to rainfall events, Environ. Sci. Technol., 44, 6305-6312, 2010.

Rozemeijer, J. C., Klein, J., Broers, H. P., van Tol-Leenders, T. P., and van der Grift, B.: Water quality status and trends in agriculture-dominated headwaters; a national monitoring network for assessing the effectiveness of national and European manure legislation in the Netherlands, Environ. Monit. Assess., 186, 8981-8995, 2014. 
Schot, P. P. and Molenaar, A.: Regional changes in groundwater flow patterns and effects on groundwater composition, J. Hydrol., 130, 151-170, 1992.

Schot, P. P. and van der Wal, J.: Human impact on regional groundwater composition through intervention in natural flow patterns and changes in landuse, J. Hydrol., 134, 297-313, 1992.

Stuyfzand, P. J. and Stuurman, R. J.: Origin, distribution and chemical mass balances of non-anthropogenic, brackish and (hyper) saline groundwaters in the Netherlands, 1st SWIM-SWICA Joint Saltwater Intrusion Conference, Cagliari-Chia Laguna, 2429 September 2006, 151-164, Italy, 2006.

Törnqvist, T. E., Wallac, D. J., Storms, J. E. A., Wallinga, J., Van Dam, R. L., Blaauw, M., Derksen, M. S., Klerks, C. J. W., Meijneken, C., and Snijders, E. M. A.: Mississippi Delta subsidence primarily caused by compaction of Holocene strata, Nat. Geosci., 1, 173-176, 2008.

Van Beek, C. L., Droogers, P., van Hardeveld, H. A., van den Eertwegh, G. A. P. H., Velthof, G. L., and Oenema, O.: Leaching of solutes from an intensively managed peat soil to surface water, Water Air Soil Poll., 182, 291-301, 2007.

van der Grift, B., Broers, H. P., Berendrecht, W., Rozemeijer, J., Osté, L., and Griffioen, J.: High-frequency monitoring reveals nutrient sources and transport processes in an agriculturedominated lowland water system, Hydrol. Earth Syst. Sci., 20, 1851-1868, https://doi.org/10.5194/hess-20-1851-2016, 2016.

Van Loon, A. H.: Unravelling hydrological mechanisms behind fen deterioration in order to design restoration strategies, $\mathrm{PhD}$ thesis, Utrecht University, Utrecht, the Netherlands, 2010.

Van Wallenburg, C.: Kattekleigronden en potentiele katteklei in droogmakerijen in het Westen van Nederland. Boor en Spade: verspreide bijdragen tot de kennis van de bodem van Nederland, 19, 116-133, 1975.
Vermaat, J. E. and Hellmann, F.: Covariance in water- and nutrient budgets of Dutch peat polders: what governs nutrient retention?, Biogeochemistry, 99, 109-126, 2010.

Vermonden, K., Hermus, M. A. A., van Weperen, M., Leuven, R. S. E. W., van der Velde, G., Smolders, A. J. P., Roelofs, J. G. M., and Hendriks, A. J.: Does upward seepage of River water and storm water runoff determine water quality of urban drainage system in lowland areas? A case study for the Rhine-Meuse delta, Hydrol. Process., 23, 3110-3120, 2009.

Vos, P.: Origin of the dutch coastal landscape: long-term landscape evolution of the Netherlands during the Holocene, described and visualized in national, regional and local palaeogeographical map series, $\mathrm{Ph}$. D. thesis, Utrecht University, Utrecht, the Netherlands, 2015.

Wade, A. J., Palmer-Felgate, E. J., Halliday, S. J., Skeffington, R. A., Loewenthal, M., Jarvie, H. P., Bowes, M. J., Greenway, G. M., Haswell, S. J., Bell, I. M., Joly, E., Fallatah, A., Neal, C., Williams, R. J., Gozzard, E., and Newman, J. R.: Hydrochemical processes in lowland rivers: insights from in situ, highresolution monitoring, Hydrol. Earth Syst. Sci., 16, 4323-4342, https://doi.org/10.5194/hess-16-4323-2012, 2012.

Wu, J. and Malmstrom, M. E.: Nutrient loadings from urban catchments under climate change scenarios: Case studies in Stockholm, Sweden, Sci. Total Environ., 518-519, 393-406, 2015.

Yan, R., Huang, J., Li, L., and Gao, J.: Hydrology and phosphorus transport simulation in a lowland polder by a coupled modeling system, Environ. Pollut., 227, 613-625, 2017. 